\title{
Bedload transport in a formerly glaciated mountain catchment constrained by particle tracking
}

\author{
A. Dell'Agnese ${ }^{1}$, F. Brardinoni ${ }^{2,5}$, M. Toro ${ }^{3}$, L. Mao ${ }^{4}$, M. Engel $^{1}$, and F. Comiti ${ }^{1}$ \\ ${ }^{1}$ Faculty of Science and Technology, Free University of Bolzano, Piazza Università 5, \\ 39100 Bozen-Bolzano, Italy \\ ${ }^{2}$ Department of Earth and Environmental Sciences, University of Milano-Bicocca, \\ Piazza della Scienza 4, 20126 Milan, Italy \\ ${ }^{3}$ Department of Civil and Environmental Engineering, University of Trento, \\ Via Belenzani 12 I, 38122 Trento, Italy \\ ${ }^{4}$ Department of Ecosystems and Environment, and Center of Applied Ecology \& Sustainability (CAPES), \\ Pontificia Universidad Católica de Chile, Avda. Libertador Bernardo O'Higgins 340, Santiago, Chile \\ ${ }^{5}$ CNR-IRPI, Corso Stati Uniti 4, 35127 Padua, Italy \\ Correspondence to: A. Dell'Agnese (andrea.dellagnese@unibz.it)
}

Received: 22 April 2015 - Published in Earth Surf. Dynam. Discuss.: 21 May 2015

Revised: 19 October 2015 - Accepted: 3 November 2015 - Published: 18 November 2015

\begin{abstract}
In formerly glaciated mountain settings, Pleistocene glaciations are responsible for profound spatial reorganization of the landscape structure. By imposing local channel slope and the degree of hillslope-channel connectivity, glacial macro-forms can exert first-order controls on the downstream strength and continuity of the coarse sediment cascade. To estimate quantitatively these controls we trace bedload transport for 3 years along Strimm Creek, Eastern Italian Alps. Specifically, we monitor the travel distance of 490 PIT-tagged particles ( $b$ axis: $23-229 \mathrm{~mm}$; weight: 83-6525 g) at two contrasting sites: Upper Strimm Creek (US; $4 \mathrm{~km}^{2}$ ), which flows through a fluvially dominated hanging valley, and Lower Strimm Creek (LS; $7.5 \mathrm{~km}^{2}$ ), located downstream, in a relict glacial trough where it experiences periodic colluvial sediment inputs from lateral tributaries. Tracer positioning within the streambed is periodically tracked in the field with a portable antenna in order to assess progressive travel distances, as well as the extent of the channel active layer, in relation to snowmelt and rainfall-driven peak flows. Interestingly, we show that tracer virtual velocities for selected inter-survey periods are independent of tracer weight at both study sites. Cumulatively, tracers in US have travelled across distances (i.e. inner quartiles) shorter than $2 \mathrm{~m}$, which correspond to over 2 orders of magnitude less than what was observed in LS. These figures translate, after calculations of tracer inter-survey virtual velocities, into estimated bedload volumes equal to about $3 \mathrm{~m}^{3}$ in US and $600 \mathrm{~m}^{3}$ in LS, with most of the transport $(75 \%$ in US, and $93 \%$ in LS) occurring during snowmelt. A similar contrast in bedload transport rates, even without considering the additional volumes of material mobilized by mass-wasting processes in LS, testifies the extent to which the glacial imprinting can still affect contemporary sediment transfer, and thus postglacial landscape evolution, in mountain drainage basins.
\end{abstract}




\section{Introduction}

The quantification of bedload transport rates and temporal variability in mountain streams is of primary importance in many applications in geomorphology, freshwater biology, and hydraulic engineering (Wohl, 2010), but these still remain very difficult to predict (e.g. Comiti and Mao, 2012). Semi-empirical transport capacity equations proposed so far offer results heavily dependent on the experimental setup of the flumes or field conditions on specific study sites in which they were originally developed. When tested in mountain streams, these equations tend to overestimate the actual bedload transport rate by several orders of magnitude, especially when applied to ordinary flood events (e.g. Bathurst, 1987; Gomez and Church, 1989; Nakato, 1990; D'Agostino and Lenzi, 1999; Rickenmann, 2001; Habersack and Laronne, 2002; Martin, 2003; Nitsche et al., 2011; Green et al., 2015), mostly due to large macro-roughness providing extra energy dissipation and to the limited sediment supply conditions typical of stepped channels draining relatively small catchments (Montgomery and Buffington, 1997). Additionally, the actual dynamics of particle movement in such streams are possibly heavily influenced by the size, frequency, and spatial arrangement of morphological units.

A number of methods have been developed to investigate bedload transport over the last century. Among these, one of the oldest is represented by tracers, first used by Gilbert and Murphy (1914) in their pioneering work on the incipient motion of bed particles. During the last 50 years, several studies involving the use of tracers of different type have been conducted (e.g. Laronne and Carson, 1976; Hassan et al., 1991, 1992, 2013; Church and Hassan, 1992; Sear et al., 2000; Lenzi, 2004; Lamarre et al., 2005; Mao and Lenzi, 2007; Schneider et al., 2010; Liébault et al., 2012). The way tracers work makes them ideal means for evaluating in-channel sediment connectivity over time (e.g. Bracken et al., 2015). In particular, they allow for gathering quantitative information on thresholds for particle entrainment, transport distances and preferential resting sites, sediment sorting by particle size or shape, and depth and width of the active layer (especially when complemented with scour chains), as well as on sediment transport rates.

The first tracers were simply painted stones (e.g. Takayama, 1965; Leopold et al., 1966), which provided valuable insights into sediment mobility (e.g. Church and Hassan, 1992) but could not be recovered if buried. Substantial improvements in the detection of buried tagged particles, and hence their recovery rate, were made by implanting small iron plates in natural clasts (surveys were conducted with a metal detector) using naturally magnetic tracers (Ergenzinger and Custer, 1983; Hassan and Ergenzinger, 2003). This technical solution allowed a more complete appraisal of the number of clasts moving from the surface to the subsurface (and vice versa), which also meant gaining a better understanding of the active channel depth.
A more sophisticated system to trace particle movement was proposed by Schmidt and Ergenzinger (1992), who implanted active transponders into pebbles. These transponders emit a unique radio frequency identification code (RFID) detected and recorded by dedicated antennas. Even though active transponders have a wide detection range (order of metres, depending on their size), their use strongly relies on the duration of the internal battery. This is the main reason why passive integrated transponders (PITs) came into play. Originally developed to track fish passage in natural streams (e.g. Armstrong et al., 1996; Johnston et al., 2009), PITs were later used to monitor sediment movement (e.g. Nichols, 2004; Lamarre et al., 2005). The antennas used to detect PITs have a relatively short detection range (up to about $1 \mathrm{~m}$, depending on PIT size; see Chapuis et al., 2014), but PITs are small (down to $1 \mathrm{~cm}$ ), cheap (approximately EUR 2.00 each) and do not require an internal battery.

Tracing the movements of single particles permits their virtual velocity to be calculated, which, when analysed together with depth and width of the active channel layer, can lead to the assessment of bedload volumes transported by sequences of discrete transport events (e.g. Haschenburger and Church, 1998). Bedload tracing performed through portable RFID antennas has been applied successfully to investigate bedload sediment dynamics in a number of fluvially dominated settings, with recovery rates ranging from $60 \%$ to $100 \%$ (e.g. Nichols, 2004; Lamarre et al., 2005; Lamarre and Roy, 2008; Schneider et al., 2010; Camenen et al., 2010; Bradley and Tucker, 2012; Liébault et al., 2012).

From a landscape evolution standpoint, monitoring bedload transport in mountain, formerly glaciated basins is key for quantifying contemporary rates of postglacial fluvial reworking in relation to landscape structure and degree of hillslope-channel geomorphic connectivity. In similar settings, the spatial organization of inherited glacial topography and glacigenic sedimentary covers - by modulating debrisflow sediment flux (Brardinoni et al., 2012), and by imposing sediment supply to stream channels (Brardinoni and Hassan, 2006; Brardinoni et al., 2009; Hoffman et al., 2013) - makes fluvial sediment dynamics at the basin scale complex and poorly understood. Although it is known that relict glacial macro-forms such has hanging valleys, valley steps, and troughs can control the spatial distribution of geomorphic process domains and channel-reach morphology (Brardinoni and Hassan, 2007; Weekes et al., 2012; Green et al., 2013), a quantitative appraisal of the glacial conditioning on contemporary rates of bedload sediment transfer is still missing.

In this paper, we used 494 PIT-tagged clasts to evaluate bedload sediment transport in two strategic study sites within Strimm Creek, a high-elevation, formerly glaciated basin of the Eastern Italian Alps. We aim to contrast the bedload transport regime of an upper site, located in a gentle hanging valley floor that is completely decoupled from colluvial sediment inputs, with the regime of a lower one located along a steep glacial trough and as such periodically affected by lat- 


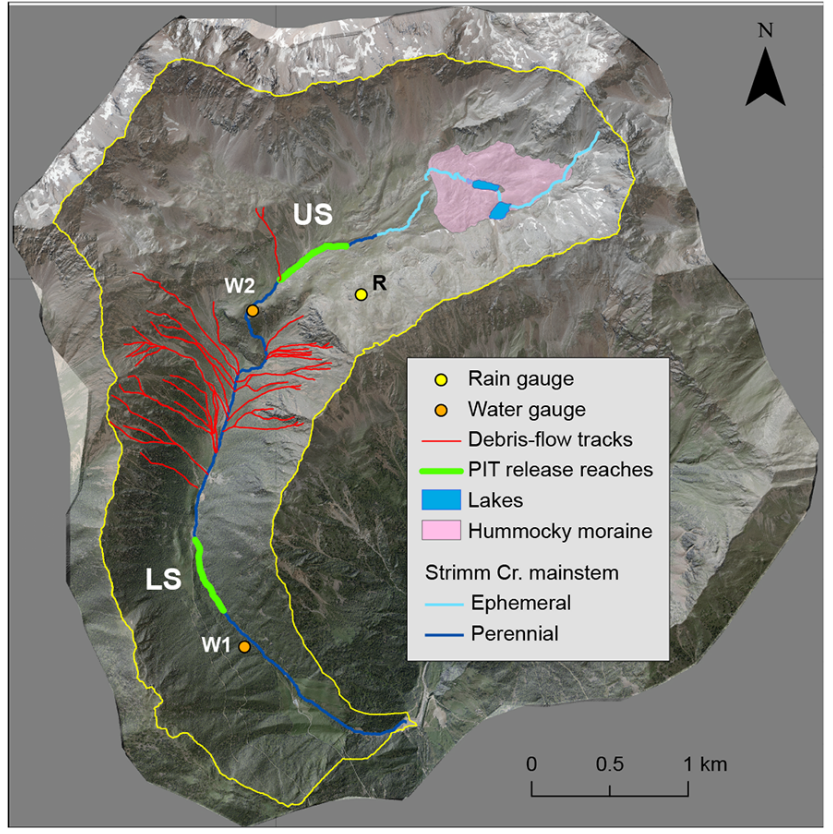

Figure 1. Map of the Strimm Creek basin showing the location of the tracers' release sites in Upper Strimm (US) and Lower Strimm (LS) along the channel main stem. Hydrologic classification was delineated during summer field surveys. Debris flowdominated tributaries (red lines) are mapped from historical aerial photo interpretation and fieldwork. WS1: water stage gauging in Lower Strimm; WS2: water stage gauging in Upper Strimm; R1: rain gauge station at Strimmhof; R2: rain gauge station in Upper Strimm; RB: retention basin at Strimm Creek outlet.

eral mass-wasting sediment inputs. In particular, we tracked travel distances of tracers by means of a portable RFID antenna from August 2011 to July 2014, and quantified bedload transport over a 3-year time period. After characterizing the downstream variability in channel boundary conditions, we analysed tracer travel distances and virtual velocities in relation to peak discharge and tracer weight. Finally, we estimated transported bedload volumes in the two study sites and put forward postglacial patterns of sediment transfer at the basin scale.

\section{Study area}

Strimm Creek (Strimmbach, Rio Strimo; drainage area $8.5 \mathrm{~km}^{2}$ ) is a rugged, formerly glaciated basin located in the upper Vinschgau/Venosta Valley, corresponding to the upper portion of the Etsch/Adige River, Eastern Italian Alps (Fig. 1). Elevation ranges from $1394 \mathrm{~m}$, at the basin outlet, to $3197 \mathrm{~m}$ a.s.l. The basin has a peculiar elongated shape, with a roughly homogeneous width of about $1 \mathrm{~km}$. Most of the upper portion of the Strimm Basin is underlain by paragneiss and schist with abundant metapegmatites of the Mazia unit (Habler et al., 2009), except for the distal-most part, in which paragneiss and orthogneiss of the Oetztal unit outcrops (Corrado Morelli, personal communication, 2015, based on unpublished data of the CARG project, Provincia Autonoma di Bolzano). The annual average precipitation in the Etsch/Adige valley is quite low, being around $480 \mathrm{~mm}$ at the valley floor (Laas/Lasa weather station, $863 \mathrm{~m}$ a.s.l., period 1989-2012), with maxima in July and August. Precipitations increase in the Lower Strimm Basin $(662 \mathrm{~mm}$, at the Strimmhof station, $1754 \mathrm{~m}$ a.s.l., period 1993-2012 - R1 in Fig. 1), and even if long-term series for the upper part of the basin are not yet available, an estimated value of about 800 $900 \mathrm{~mm}$ is probable. At the Strimmhof station, the maximum precipitation over a $24 \mathrm{~h}$ period recorded between 1993 and 2012 amounts to $72 \mathrm{~mm}$. Since July 2011, a non-heated rain gauge (R2, Fig. 1) powered by a solar panel was installed at $2560 \mathrm{~m}$ a.s.l. to monitor summer (May to October) rainstorms triggering debris flows in the adjacent Gadria Creek (Comiti et al., 2014). Snow cover in the intermediate and upper parts of the Strimm Basin usually lasts from November to early June, but largely varies depending on site aspect.

Currently active geomorphic processes include periglacial, colluvial, and fluvial transport. Periglacial activity is prevalent on the talus slopes of the Upper Strimm Basin, as testified by the presence of intact rock glaciers on east- and northfacing slopes above $2600 \mathrm{~m}$ a.s.l. Perennial fluvial transport regime characterizes the lower half of the hanging valley floor (channel slope range: 1-10\%) downstream of the large hummocky moraine, and down to the basin outlet (Fig. 1). This upper part of the study stream is disconnected from lateral colluvial sediment inputs (Fig. 2a and b) except at one location, where small debris flows deliver material eroded from a till-mantled valley side (Fig. 1). In the middle part of the basin (slope range of channel main stem: 10-25\%), downstream of the rocky valley step that marks the transition between the hanging valley and the steep glacial trough, debris slides and channelized debris flows convey colluvial material from hillslope tributaries to the main channel. In the distal part, downstream of WS1 (Fig. 1), Strimm Creek deviates towards south-east flowing in a structurally controlled, Vnotched valley step with no lateral tributary (Fig. 2d). Here, open-slope debris slides and bank failures deliver material directly to the channel. This is the steepest part of Lower Strimm, with channel slope ranging between 12 and $42 \%$.

The bedload monitoring sites are located within the hanging valley floor (Upper Strimm) and downstream of the rocky valley step (Lower Strimm). Upper Strimm Creek, hereafter termed US (average slope $=8 \%$ ), is characterized by plane-bed and step-pool channel morphologies (Fig. 2a and b). Lower Strimm Creek, hereafter termed LS (average slope $=15 \%$ ), is dominated by boulder-cascade and step-pool morphologies (Fig. 2c and d). The former is located at about $2550 \mathrm{~m}$ a.s.l., above the tree line, while the latter sits at about $1850 \mathrm{~m}$ and flows amidst coniferous forest dominated by European larch (Larix decidua (M.)) and Norway spruce (Picea abies (L.)). 


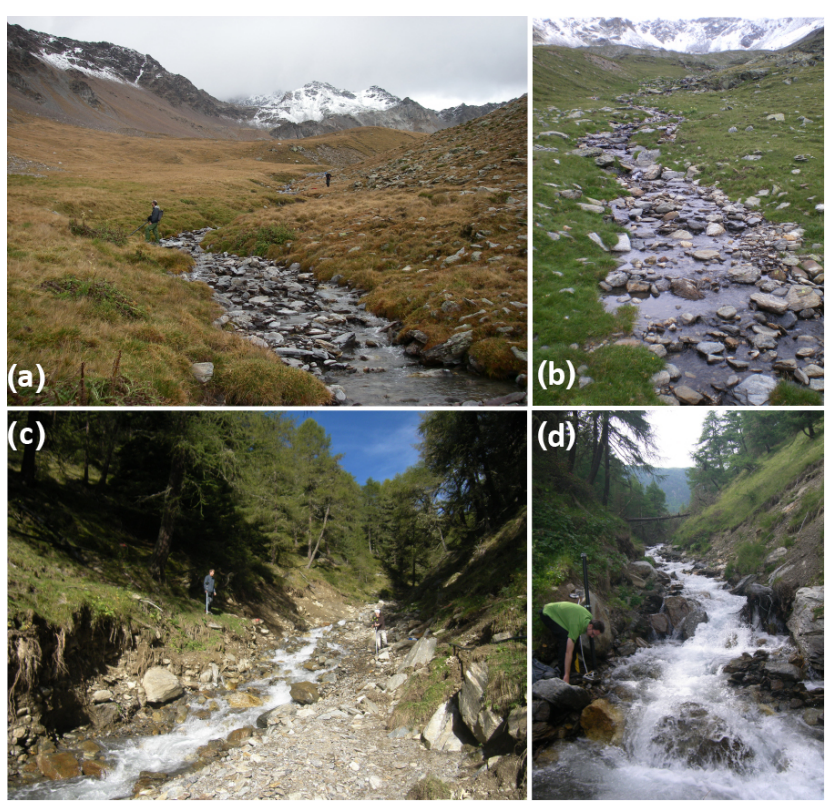

Figure 2. (a) Upper Strimm flowing across the hanging valley floor in decoupled conditions. (b) Detail of rapids channel-reach morphology (i.e. transverse ribs on a shallow bed) under low-flow conditions (channel width $=4 \mathrm{~m}$ ). (c) Lower Strimm in strongly coupled conditions characterized by step-pool and boulder-cascade morphology under low-flow conditions with banks eroded by the 2010 debris flow (channel width $=4.5 \mathrm{~m}$ ). (d) The water gauging station (WS1) to the left of the picture.

\section{Methods}

Water stage monitoring was conducted by means of two stand-alone, battery-powered pressure transducers installed at the downstream end of the hanging valley (WS2, Fig. 1, elevation $2430 \mathrm{~m}$ a.s.l., drainage area $4 \mathrm{~km}^{2}$ ) and near the basin outlet (WS1, Fig. 1, elevation $1830 \mathrm{~m}$ a.s.l., drainage area $7.5 \mathrm{~km}^{2}$ ). Both stations recorded water level every $10 \mathrm{~min}$, year-round. Relevant flow rating curves were derived from salt dilution (slug injection) discharge measurements. Owing to frequent cross-sectional changes at WS1, we used this station only for confirming the occurrence of flood events, whereas the quantitative analysis on particle displacement at US and LS was based on WS2 flow data, where the cross section remained stable over the entire period. Based on 10 concurrent discharge measurements, flows in WS1 were on average $60 \%$ higher than at WS2 during snowmelt, and about $100 \%$ higher during summer low flows. Errors associated with these estimates will be later accounted for in the analysis of Lower Strimm.

Before preparing the PIT-tagged stones for bedload tracing, we characterized the surface grain-size distribution at US and LS. This was performed through 34 grid-by-number pebble count samples (grid spacing $0.3 \mathrm{~m}$ at US, $0.5 \mathrm{~m}$ at LS; Bunte and Abt, 2001). Surface grain-size curves were then derived for both sites by integrating all 34 samples
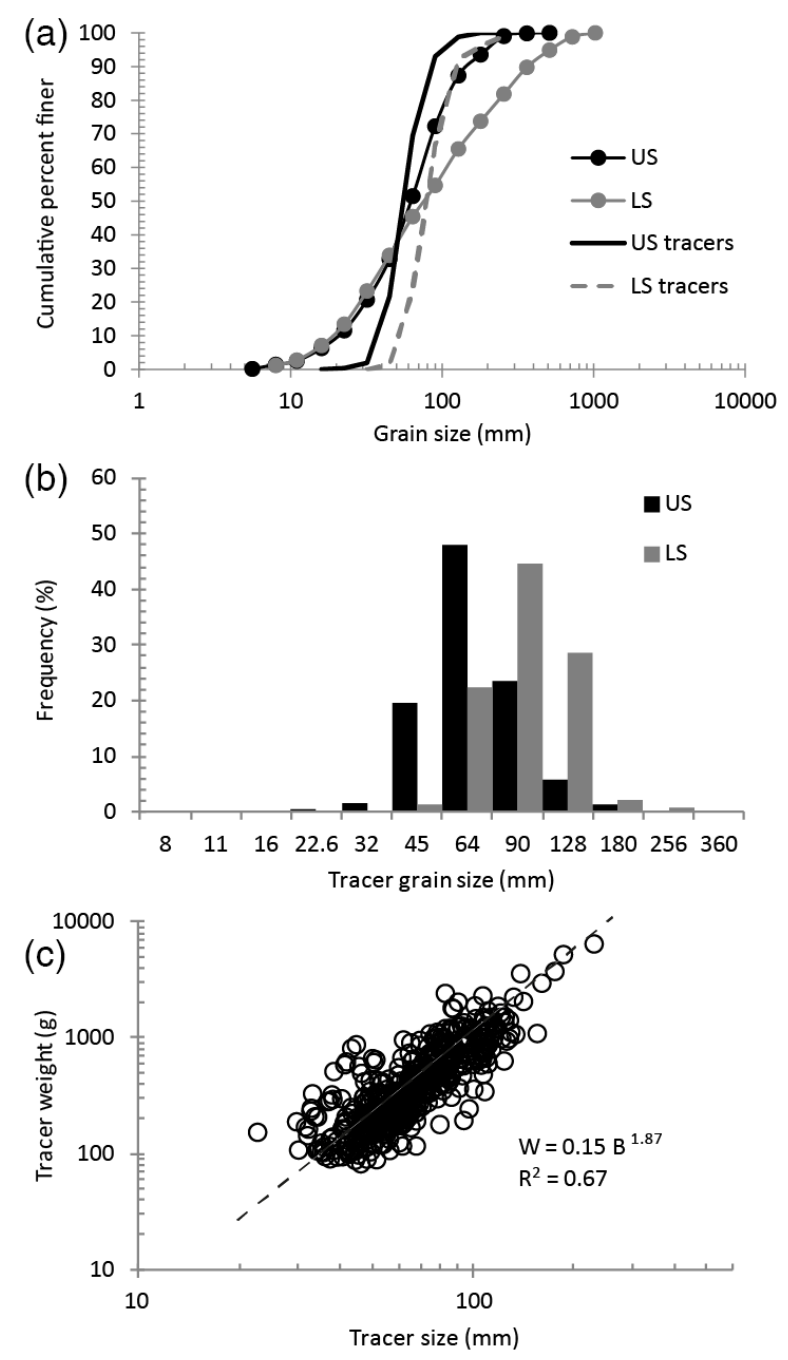

Figure 3. (a) Bed surface and tracer cumulative grain-size distribution in US $\left(D_{30}=42 \mathrm{~mm}, D_{50}=62 \mathrm{~mm}, D_{84}=119 \mathrm{~mm}\right.$, and $\left.D_{90}=148 \mathrm{~mm}\right)$ and LS $\left(D_{30}=40 \mathrm{~mm}, \quad D_{50}=76 \mathrm{~mm}\right.$, $D_{84}=281 \mathrm{~mm}$ and $D_{90}=368 \mathrm{~mm}$ ). (b) Corresponding noncumulative tracer size ( $b$ axis) distributions. (c) Tracer weight as a function of tracer size ( $b$ axis).

(Fig. 3a). In the upper study area, sediments ranged from 4 to $512 \mathrm{~mm}$, with $D_{16}=26.7 \mathrm{~mm}, D_{50}=62.3 \mathrm{~mm}$, and $D_{84}=118.6 \mathrm{~mm}$. The lower study area was comparatively coarser, with $b$ axis varying from 5.6 to $1024 \mathrm{~mm}$, and a much more heterogeneous distribution $\left(D_{16}=24.8 \mathrm{~mm}\right.$; $D_{50}=76.1 \mathrm{~mm} ; D_{84}=281.3 \mathrm{~mm}$ ).

To investigate bed mobility, particle travel distances, and bedload volumes in the two contrasting study sites (US and LS) of Strimm Creek, we used painted, PIT-tagged clasts. PITs (23.1 $\mathrm{mm}$ long and $3.85 \mathrm{~mm}$ in diameter) manufactured by Texas Instruments were implanted within drilled clasts and glued into the holes with epoxy resin. PIT-tagged clasts were simply placed on the streambed as transverse ribs along the study sites with a downstream spacing of $5 \mathrm{~m}$ in US and 
Table 1. Summary information on the tracer clasts released at Upper Strimm and Lower Strimm.

\begin{tabular}{rrrrrrrc}
\hline Site & $\begin{array}{r}\text { Release } \\
\text { date }\end{array}$ & $N$ & \multicolumn{2}{c}{$B$ axis $(\mathrm{mm})$} & \multicolumn{2}{c}{ Weight $(\mathrm{g})$} & Rib spacing \\
& $\min$ & $\max$ & $\min$ & $\max$ & $(\mathrm{m})$ \\
\hline \multirow{4}{*}{ US } & 31 Aug 2011 & 80 & 23 & 155 & 89 & 1129 & 5 \\
& 28 Sep 2011 & 79 & 37 & 102 & 117 & 1482 & 5 \\
& 14 Jun 2012 & 100 & 34 & 108 & 92 & 1432 & 5 \\
\hline \multirow{4}{*}{ LS } & 25 Jul 2011 & 101 & 35 & 229 & 83 & 6525 & 3 \\
& 29 Aug 2011 & 69 & 43 & 160 & 177 & 3085 & 3 \\
& 7 Jul 2013 & 61 & 49 & 132 & 179 & 2328 & 3 \\
\hline
\end{tabular}

$3 \mathrm{~m}$ in LS. Each rib at US consisted of three to four clasts, one of which always located on the thalweg, and the other two near the banks. At LS, ribs consisted of four clasts, two of which were always deployed in the centre of the channel. In order to assess the variability of active channel width during higher flows, additional clasts were added to a given transverse rib in correspondence to bars or other lateral deposits.

In the US study site we released 259 painted PITs (Table 1) ( $b$ axis ranging from 23 to $155 \mathrm{~mm}$; weight from 89 to $1482 \mathrm{~g}$ ) in three sequential sets: on 31 August 2011 (80 PITs), 28 September 2011 (79 PITs), and 14 June 2012 (100 PITs). At LS, we released 231 painted PITs ( $b$ axis ranging from 35 to $229 \mathrm{~mm}$; weight from 83 to $6525 \mathrm{~g}$ ) (Table 1). Initially, we released 101 painted PITs on 25 July 2011 and 69 more on 29 August 2011. On 4 July 2013, 61 additional clasts ( $b$ axis ranging from 48 to $132 \mathrm{~mm}$ ) were released at the same site as a consequence of the intense snowmelt recorded in summer 2013, during which 120 tracers of the initial ones exited the study area travelling to the steep and inaccessible downstream-most reach. The grain-size distributions of the tracer particles released in the two study sites mimicked the coarser nature of LS in comparison to US (Fig. 3b), with the minimum tracer size dictated by the size of the PIT tags (i.e. we could not trace clasts with $b$ axis $<23 \mathrm{~mm}$ ). While in US we were able to trace the entire natural range of grain-size variability (i.e. $>23 \mathrm{~mm}$ ), in LS, for logistical reasons, we could not tag clasts comprised between 230 and $1024 \mathrm{~mm}$.

A detailed topographic survey at US was performed during 2011-2012 by means of a monopod laser range finder (MDL LaserAce 300), for a total surveyed length of $1093 \mathrm{~m}$. The survey featured a minimum density of 3 points $\mathrm{m}^{-1}$ along the thalweg, with additional points collected on the active streambed to define macro-forms. The topographic survey of the LS segment (total length $1514 \mathrm{~m}$ ) was performed earlier, during October 2010 and May 2011, with a Leica T1000 total station. This survey featured a minimum point density of 2 points $\mathrm{m}^{-1}$ along the thalweg, with several additional points surveyed to better define the step-pool morphology and avoid data loss due to the smoothing of the model. Concurrently, we surveyed a total of 120 channel cross sections at intervals of 20 and $25 \mathrm{~m}$ respectively in US and LS
(Fig. 1). The digital delineation of the main channel, the derivation of the contributing area $(A)$, and the characterization of relevant channel boundary conditions (i.e. local channel slope $(S)$, and indices of total $(\Omega)$ and unit $(\omega)-$ stream power) was conducted via integration of the aforementioned field-based data with aerial photo interpretation and an airborne lidar-derived $1 \mathrm{~m}$ DEM acquired in 2011 (Fig. 1). Indices of total stream power $(\Omega=A S)$ and specific stream power $\left(\omega=A S / w_{\text {bf }}\right)$ were obtained by replacing water discharge with contributing area (e.g. Brummer and Montgomery, 2003).

Bedload tracing was conducted by means of portable RFID antennas (one manufactured by AQUARTIS, one by Oregon RFID; vertical and horizontal detection range is approximately equal to $0.5 \mathrm{~m}$ ) from spring to autumn depending on the occurrence of flow events (e.g. snowmelt, rainfallinduced, and a combination of the two; Fig. 4). The relative position of each clast was measured by means of a TriPulse 360 B laser rangefinder (Laser Technologies Inc.) from a series of georeferenced control points along the topographic net created during the 2010-2012 surveys, so that, after each survey, it was possible to derive the absolute position of the clasts. The relative displacement of each tracer was then calculated by measuring along the thalweg the distance from their actual position to the position identified during the previous survey.

Even though we have measured the three axes of each tracer stone, we will show the results of travel distance in relation to tracer weight only. This is because exploratory analysis of travel distance distributions in relation to grainsize classes displayed high variability among classes (likely due to their highly variable shapes), and assessing the effect of particle shape on sediment transport is beyond the scope of this work. For reference, we report the relation between tracer weight and tracer $b$ axis $\left(R^{2}=0.67\right.$; Fig. $\left.3 \mathrm{c}\right)$. In our analysis, the tagged particles were grouped into eight weight categories: W1 to W6 in US, and W1 to W8 in LS (Table 2; table also provides information about the clast count/weight class both at LS and US). At US, the uncertainty associated with the positioning of single tracers due to instrumental errors was estimated to be $0.2 \mathrm{~m}$. Here the painted PITs were consistently visible during fieldwork thanks to the low turbulence and rare burial conditions. By contrast, in LS, where often clasts were buried or difficult to locate with greater accuracy due to the more turbulent nature of the flow and the rougher bed texture, instrumental uncertainty was estimated to be up to $0.5 \mathrm{~m}$. All estimated movements lower than these tolerance thresholds were discarded from the analysis.

We used the flow competence method for assessing sediment mobility (e.g. Andrews, 1983), with the minimum discharge able to entrain clasts of each weight class identified based on the field surveys. The threshold discharge value associated with the motion of each weight class was defined 


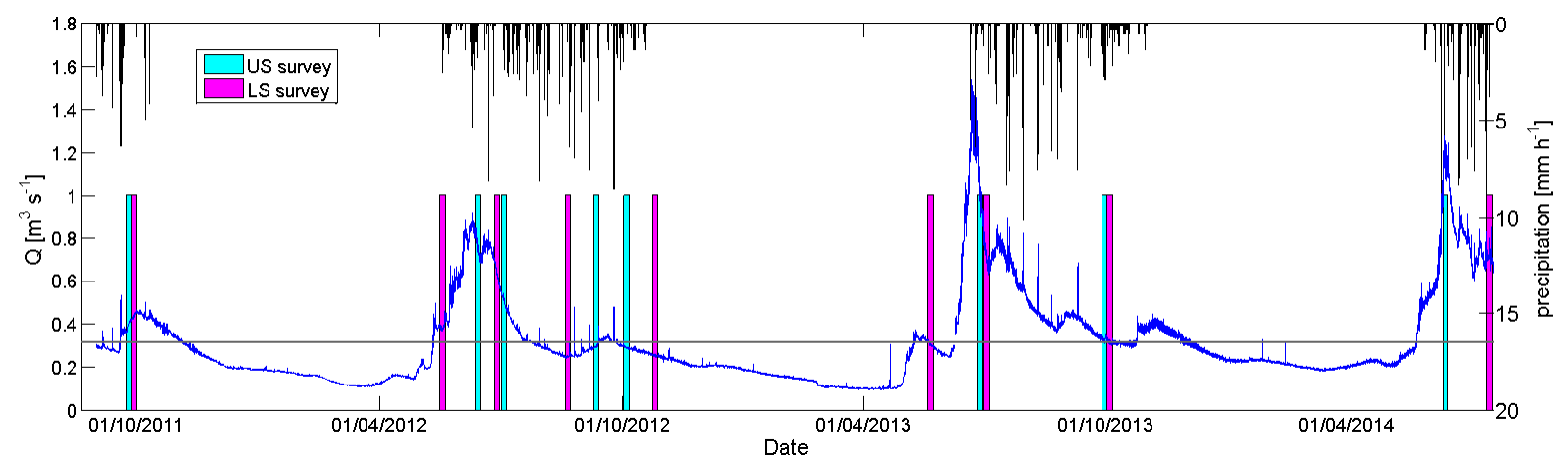

Figure 4. Water discharge hydrograph at WS2 station and the temporal distribution of tracer surveys in US (cyan bars) and LS (purple bars). Black vertical black bars indicate hourly rainfall intensity recorded at the non-heated pluviometer (R2). The black horizontal line marks the lowest $Q_{\max }$ for which bedload movement was recorded at US.

Table 2. Tracer clast distributions across weight categories ( $\mathrm{g}$ ) in US and LS.

\begin{tabular}{|c|c|c|c|c|c|c|c|c|c|}
\hline \multicolumn{2}{|c|}{ Weight category } & W1 & W2 & W3 & W4 & W5 & W6 & W7 & W8 \\
\hline \multicolumn{2}{|c|}{ Weight range $(\mathrm{g})$} & $<200$ & $201-400$ & $401-600$ & $601-800$ & $801-1000$ & $1001-1500$ & $1501-3000$ & $>3000$ \\
\hline \multirow{2}{*}{ US } & Clast count & 72 & 91 & 43 & 13 & 7 & 6 & 0 & 0 \\
\hline & Percent & 31.03 & 39.22 & 18.53 & 5.60 & 3.02 & 2.59 & 0 & 0 \\
\hline \multirow{2}{*}{ LS } & Clast Count & 21 & 48 & 44 & 35 & 28 & 36 & 16 & 4 \\
\hline & Percent & 9.05 & 20.69 & 18.97 & 15.09 & 12.07 & 15.52 & 6.90 & 1.72 \\
\hline
\end{tabular}

as

$Q_{t i}=\min \left\{\max \left(Q_{i}\right) ; \min \left(\bar{Q}_{i}\right)\right\}$,

where $Q_{i}$ are the discharge values for which clasts from the $i$ th weight class remained immobile and $\bar{Q}_{i}$ the values for which clasts of the $i$ th weight class moved.

Virtual velocities were quantified considering the displacement length and the duration of over-threshold flows between two subsequent surveys and were used to estimate the total sediment transported during the survey period. This approach was preferred over a shear-stress-based one due to the extremely rough geometry of the channel, which would have made the estimation of the water depth at different sections subject to greater uncertainties (Comiti and Mao, 2012). Following Liébault and Laronne (2008), among others, the volumetric bedload transport rate for each weight class $\left(G_{i}\right.$ $\left[\mathrm{m}^{3} \mathrm{~s}^{-1}\right]$ ) was assessed as

$G_{i}=d_{\mathrm{s}} w_{\mathrm{s}} \overline{v_{i}}(1-p)(i=1, \ldots, 8)$,

where $w_{\mathrm{s}}[\mathrm{m}]$ is the mean width of the active channel bed, $d_{\mathrm{s}}$ $[\mathrm{m}]$ the depth of the active layer of sediments, $\bar{v}_{i}$ the mean virtual velocity of the $i$ th-class transported clasts, and $p$ the fractional porosity of channel sediment (here assumed to be equal to 0.3, a typical value following Bunte and Abt, 2001). The volumetric transport rate of each class was then multiplied by the integral transport time (i.e. total time for which the threshold discharge value was reached or trespassed). The total inter-survey volumetric transport rate was then derived as

$G=\sum_{i=1}^{8} G_{i}$.

The depth of the active layer was estimated to be equal to the maximum diameter ( $b$ axis) of the locally displaced particles (Table 1 and Fig. 3). This approximation, which is based on digging tests conducted on a subset of buried tracer stones in US $(n=20$; burial depth range: $4-14 \mathrm{~cm}$; mean burial depth $=9 \mathrm{~cm}$ ), is in agreement with a recent study conducted in high-gradient, boulder-bed streams in the Alps showing that during ordinary events the thickness of the active layer ranges between 0.01 and $0.22 \mathrm{~m}$ (Schneider et al., 2014). Furthermore, Houbrechts et al. (2012) showed that the thickness of the active layer in mountain streams is typically lower than the $D_{50}$.

Because the main channel is well confined in both study sites, and since the distribution of tracer travel distances across single transverse ribs did not show any cross-sectional variability (i.e. tracers located near the banks or in the centre of the streambed displayed the same degree of mobility), we approximated active channel width with the local bankfull width in US and LS, which is 3.5 and $4 \mathrm{~m}$, respectively (Fig. 5). 
Table 3. Recovery rates per survey in US.

\begin{tabular}{lllllll}
\hline Survey (US) & $\begin{array}{l}Q_{\max } \\
\left(\mathrm{m}^{3} \mathrm{~s}^{-1}\right)\end{array}$ & $\begin{array}{l}\text { Mobilized } \\
\text { clasts (\%) }\end{array}$ & $\begin{array}{l}\text { Mobilized } \\
\text { classes }\end{array}$ & $\begin{array}{l}\text { Max travel } \\
\text { distance }(\mathrm{m})\end{array}$ & $\begin{array}{l}\text { Inter-survey } \\
\text { nant regime }\end{array}$ & $\begin{array}{l}\text { domi- } \\
\text { rate }\end{array}$ \\
\hline 28 Sep 2011 & 0.36 & $3.8 \%$ & $\mathrm{~W} 2, \mathrm{~W} 3, \mathrm{~W} 5$ & 1.2 & Rainfall & $100 \%$ \\
14 Jun 2012 & 0.66 & $27.7 \%$ & $\mathrm{~W} 1$ to W6 & 4.5 & Snowmelt & $100 \%$ \\
3 Jul 2012 & 0.55 & $4.6 \%$ & $\mathrm{~W} 1, \mathrm{~W} 2$ & 3.4 & Snowmelt & $100 \%$ \\
11 Sep 2012 & 0.33 & $17.3 \%$ & $\mathrm{~W} 1$ to W5 & 3.9 & Rainfall & $98.5 \%$ \\
4 Oct 2012 & 0.32 & $4.3 \%$ & W1 to W3 & 1.6 & Rainfall & $97.7 \%$ \\
27 Jun 2013 & 1.13 & $50.8 \%$ & W1 to W6 & 35.0 & Snowmelt & $93.4 \%$ \\
1 Oct 2013 & 0.72 & $38.1 \%$ & W1 to W6 & 12.0 & Mixed & $92.3 \%$ \\
13 Jun 2014 & 0.95 & $40.6 \%$ & W1 to W6 & 23.9 & Snowmelt & $90.3 \%$ \\
\hline
\end{tabular}
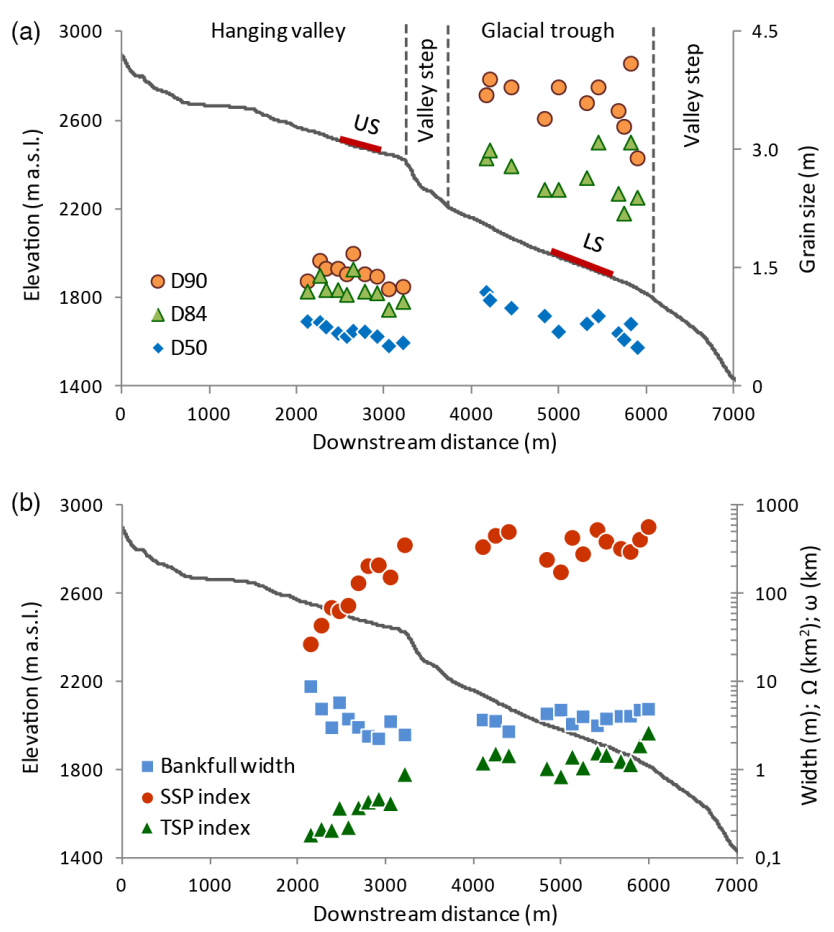

Figure 5. Longitudinal profile of Strimm Creek and the downstream variation of (a) $D_{50}, D_{84}$, and $D_{90}$ and (b) bankfull channel width and indices of total $(\Omega)$ and specific $(\omega)$ stream power. US and LS mark the locations of tracers' release.

\section{Results}

\subsection{Downstream variability in channel characteristics}

Inspection of characteristic percentiles (i.e. $D_{50}, D_{84}$, and $D_{90}$ ) of surface grain-size distribution as a function of downstream distance (Fig. 5a), while confirming that surface bed texture is considerably coarser in LS than in US, indicates consistent patterns of downstream fining within the two sites. These patterns are interrupted by the rocky valley step that separates the decoupled hanging valley from the glacial trough, downstream of which sediment calibre resets at markedly higher values, as lateral sediment supply from debris-flow-dominated tributaries feeds Lower Strimm Creek. Downstream fining, in terms of $D_{50}$, appears to be more efficient in LS than in US: i.e. $D_{50}$ declines from 120 to $50 \mathrm{~mm}$ in LS, and from 83 to $52 \mathrm{~mm}$ in US, which correspond to average fining rates of $40.5 \mathrm{~mm} \mathrm{~km}^{-1}$ in LS and $28.4 \mathrm{~mm} \mathrm{~km}^{-1}$ in US. In comparison, the coarser fractions exhibit a much higher scatter in the distal portion of LS, where downstream fining is less obvious.

Bankfull channel width exhibits a complex behaviour. At the headwaters we observe strong downstream narrowing followed by some widening in the distal part of US (Fig. 5b). Downstream narrowing is due to the morphological transition from ephemeral, poorly defined wide and shallow bed (Fig. 2b), where channelized runoff is quickly increased by subsurface flows moving away from the hummocky moraine (i.e. the lake area in Fig. 1) to a perennial channel characterized by a defined alluvial bed and higher channel banks (Fig. 2c). Downstream widening continues gradually along LS (Fig. 5b). Both indices of total and unit stream power increase fast throughout US, with a maximum in the US distalmost cross sections, and stay nearly constant along LS, with locally high fluctuations especially in terms of total stream power (Fig. 5b).

\subsection{Particle displacement in Upper Strimm}

The first survey, performed on 28 September 2011 (intersurvey maximum water discharge $Q_{\max }=0.36 \mathrm{~m}^{3} \mathrm{~s}^{-1}$ ), showed that 77 out of the initial 80 deployed clasts remained immobile, and that the other 3 clasts moved for a maximum distance of $1.2 \mathrm{~m}$. No clast from classes $\mathrm{W} 1$, W4 or W6 moved (Table 3). The survey performed on 14 June $2012\left(Q_{\max }=0.66 \mathrm{~m}^{3} \mathrm{~s}^{-1}\right)$, immediately after the end of the snowmelt period, showed that 44 out of 159 clasts had moved, with displacements occurring in all weight classes, and a maximum travel distance of $4.5 \mathrm{~m}$. By 3 July 2012 (inter-survey maximum discharge of $0.55 \mathrm{~m}^{3} \mathrm{~s}^{-1}$ ) only 12 clasts out of 259 experienced mobility (maximum displacement $=3.4 \mathrm{~m}$ ), and no movement recorded for clasts belonging to classes W3 to W6. On 11 September 2012 $\left(Q_{\max }=0.33 \mathrm{~m}^{3} \mathrm{~s}^{-1}\right)$, the survey showed that 44 clasts (out of 255 recovered) moved over a maximum distance of $3.9 \mathrm{~m}$, 

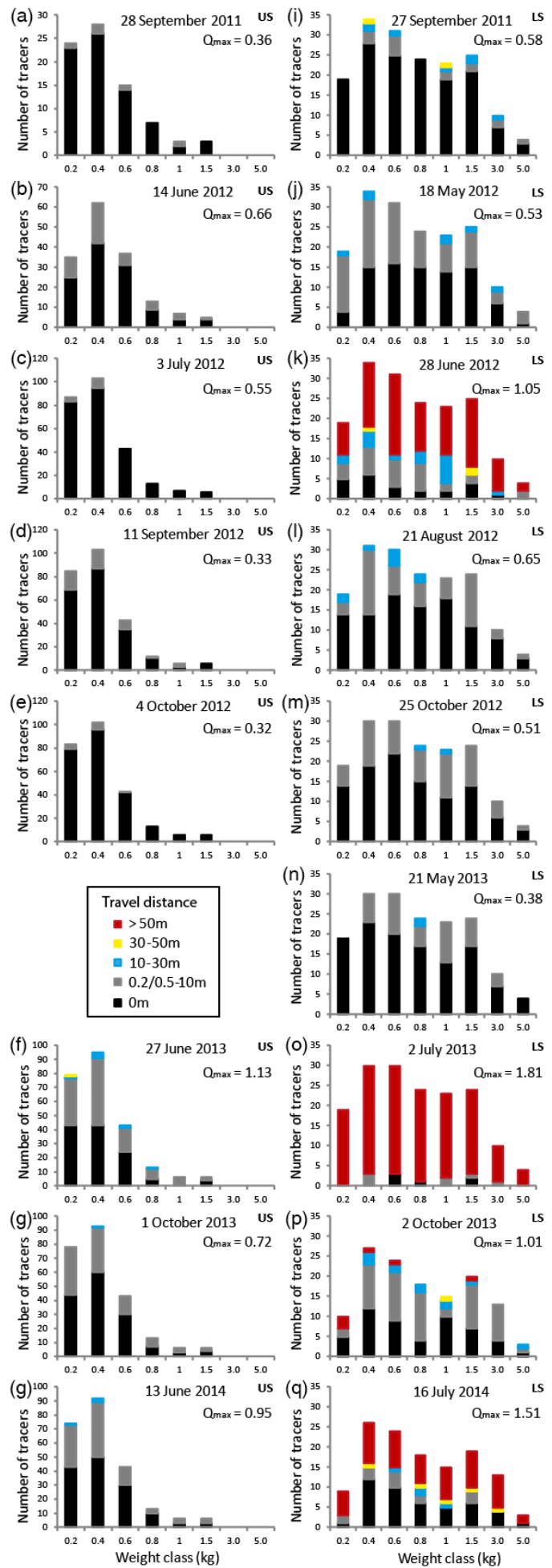

Figure 6. Stacked bar graphs showing the inter-survey frequency distributions of tracer travel distances across weight categories. Travel distances are stratified into five classes including: no motion, $<10,10-30,30-50$, and $>50 \mathrm{~m}$. Note disparity in travel distances between US (left-hand panels) and LS (right-hand panels).
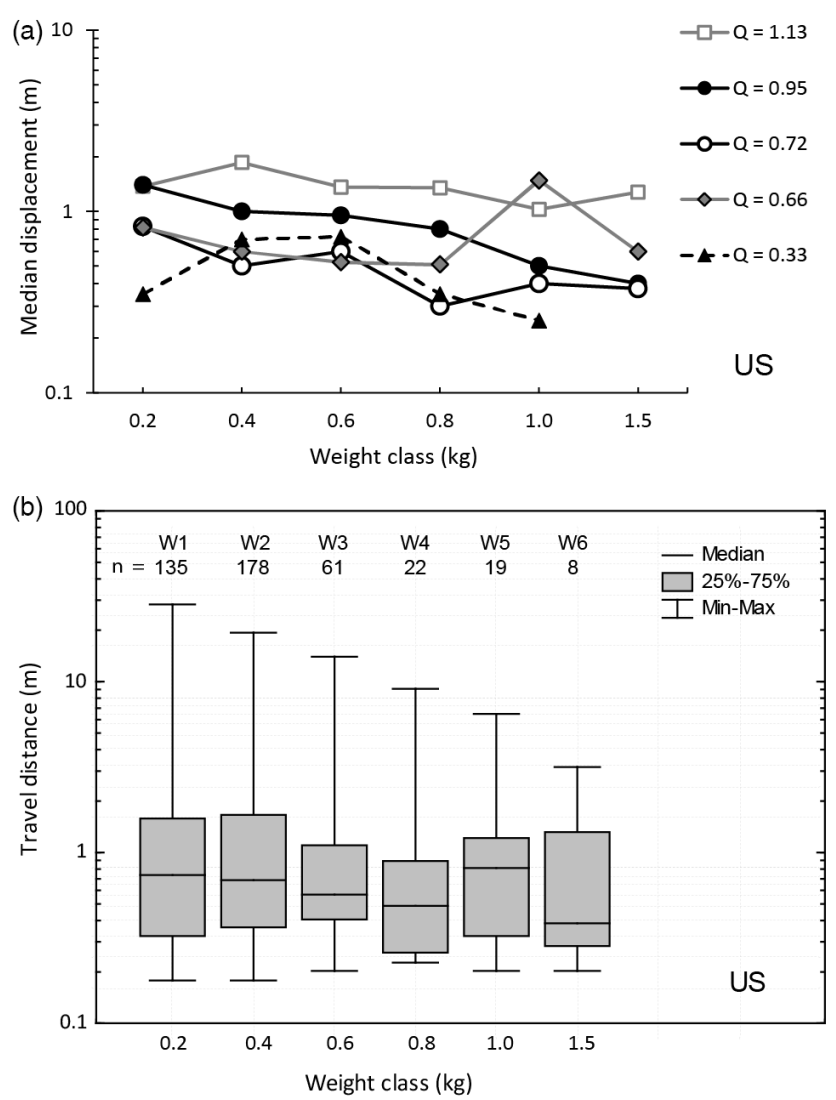

Figure 7. (a) Tracer median travel distance as a function of weight and stratified by inter-survey peak discharge $\left(Q_{\max }\right)$ in Upper Strimm (US). (b) Box plot showing the distribution of tracer travel distances across weight classes in Upper Strimm (US). No motion counts are excluded.

with no movement in class W6 (Table 3). By 4 October 2012 $\left(Q_{\max }=0.32 \mathrm{~m}^{3} \mathrm{~s}^{-1}\right)$ only 11 clasts out of the 253 recovered were entrained, with no motion in classes W4 to W6, and a maximum travel distance of $1.6 \mathrm{~m}$ for one clast in class $\mathrm{W} 2$.

Due to a deep snowpack present on the ground until late spring 2013, the snowmelt season of this year featured high discharges sustained for a long period (cf. Fig. 4). Accordingly, on 27 June $2013\left(Q_{\max }=1.13 \mathrm{~m}^{3} \mathrm{~s}^{-1}\right)$ we recorded the motion of 123 clasts (out of 242 recovered) for up to $35 \mathrm{~m}$ ( 1 clast in class W1), which represents the maximum distance recorded in US during the entire study period. The last 2013 survey was conducted on 1 October $\left(Q_{\max }=0.72 \mathrm{~m}^{3} \mathrm{~s}^{-1}\right)$, when 91 clasts (out of 239 recovered) belonging to all weight classes moved (maximum displacement of $12 \mathrm{~m}$ for a particle in W2) (Table 3). The final survey was associated with the snowmelt of 2014. On 13 June $2014\left(Q_{\max }=0.95 \mathrm{~m}^{3} \mathrm{~s}^{-1}\right)$ we recorded 95 displaced clasts (out of 234 recovered), with a maximum distance of $23.8 \mathrm{~m}$.

A comprehensive view of the eight field surveys in US can be obtained by plotting histograms of clasts displaced stratified by five travel distance categories and by tracer weight 
Table 4. Recovery rates per survey in LS. Rates of the last two surveys are low because several clasts had exited the outlet cross section of the LS study area.

\begin{tabular}{lllllll}
\hline Survey (LS) & $\begin{array}{l}Q_{\max } \\
\left(\mathrm{m}^{3} \mathrm{~s}^{-1}\right)\end{array}$ & $\%$ mobile & Mobilized classes & $\begin{array}{l}\text { Max travel } \\
\text { distance (m) }\end{array}$ & $\begin{array}{l}\text { Inter-survey domi- } \\
\text { nant regime }\end{array}$ & $\begin{array}{l}\text { Recovery } \\
\text { rate }\end{array}$ \\
\hline 27 Sep 2011 & 0.58 & $14.1 \%$ & W2, W3, and W5 to W8 & 33.9 & Rainfall & $100 \%$ \\
18 May 2012 & 0.53 & $49.4 \%$ & W1 to W8 & 17.2 & Mixed & $100 \%$ \\
28 Jun 2012 & 1.05 & $86.5 \%$ & W1 to W8 & 936.8 & Snowmelt & $100 \%$ \\
21 Aug 2012 & 0.65 & $37.6 \%$ & W1 to W8 & 21.7 & Mixed & $97.1 \%$ \\
25 Oct 2012 & 0.51 & $36.6 \%$ & W1 to W8 & 21.1 & Rainfall & $96.5 \%$ \\
21 May 2013 & 0.38 & $26.8 \%$ & W2 to W7 & 10.8 & Snowmelt & $96.5 \%$ \\
2 Jul 2013 & 1.81 & $96.3 \%$ & W1 to W8 & 926.9 & Snowmelt & $96.5 \%$ \\
2 Oct 2013 & 1.01 & $60.0 \%$ & W1 to W8 & 959.3 & Mixed & $56.0 \%$ \\
16 Jul 2014 & 1.51 & $64.6 \%$ & W1 to W8 & 958.3 & Snowmelt & $54.7 \%$ \\
\hline
\end{tabular}

classes (Fig. 6, left-hand panels; Table S1 in the Supplement). This representation shows how larger proportions of tracers are systematically displaced by snowmelt flows compared to rainfall-related ones. This is exemplified by surveys conducted in June, during which some movement was recorded in all weight classes (W1 to W6) (Fig. 6b, f and h).

For each inter-survey value of $Q_{\max }$, weight classes were plotted against the median travel distance during that period (Fig. 7a). These plots suggest that median transport distances are only weakly influenced by peak discharge (all values lie within 1 order of magnitude). Box plots of tracer travel distance $(d)$ across weight classes $(W)$ (Fig. 7b), in which "no motion" counts are not included, show that median values (and maximum values even more) decrease progressively for heavier particles. In this context, category W5 is the exception, likely due to the limited number of observations (i.e. 7). The 1 order of magnitude decline of the maximum travel distance (i.e. $d_{\max }$ decreases from $35 \mathrm{~m}$ (W1) to $3.9 \mathrm{~m}$ (W6)) indicates that increasingly heavier clasts are bound to travel less and less, in agreement with what was observed in Fig. 7 a.

\subsection{Particle displacement in Lower Strimm}

The first survey, completed on 27 September 2011 $\left(Q_{\max }=0.58 \mathrm{~m}^{3} \mathrm{~s}^{-1}\right)$, showed that only 24 PITs moved, with maximum travel distances of $33.9 \mathrm{~m}$ (class W2), $30.6 \mathrm{~m}$ (W5), and greater than $10 \mathrm{~m}$ (W3, W6, and W7), and no motion recorded in W1 and W4 (Table 4). The survey conducted on 18 May $2012\left(Q_{\max }=0.53 \mathrm{~m}^{3} \mathrm{~s}^{-1}\right)$ showed that 84 out of 170 clasts moved, with maximum travel distances of $6.1 \mathrm{~m}$ (W4) and $17.2 \mathrm{~m}$ (W5). Travel distances increased substantially due to the peak snowmelt discharge $\left(Q_{\max }=1.05 \mathrm{~m}^{3} \mathrm{~s}^{-1}\right)$, so that by 28 June 2012 only 23 out of 170 clasts remained immobile, while the others moved over greater distances (1 order of magnitude) than previously observed. Specifically, 26 clasts moved between 300 and $500 \mathrm{~m}$, and 11 over $500 \mathrm{~m}$, with a peak travel distance of $937 \mathrm{~m}$ (W8 peak travel distance $=238 \mathrm{~m}$ ). During the inter-survey period ending on 21 August 2012, peak discharge lowered considerably $\left(Q_{\max }=0.65 \mathrm{~m}^{3} \mathrm{~s}^{-1}\right)$, returning to values compara- ble to those recorded in May. As a consequence, travel distances mimicked those observed in May, with 62 particles (out of 165 recovered) displaced. Maximum travel distance was highest in W3 $(21.7 \mathrm{~m})$ and lowest in W8 $(1.7 \mathrm{~m})$, and 9 clasts belonging to classes $\mathrm{W} 1$ and $\mathrm{W} 4$ moved further than $10 \mathrm{~m}$ (Table 4). On 25 October 2012, after a period characterized by slightly lower peak discharge $\left(Q_{\max }=0.51 \mathrm{~m}^{3} \mathrm{~s}^{-1}\right)$, we recorded results in line with what was observed in the previous survey: with 60 clasts (out of 164 recovered) displaced. Among these, 58 travelled $<10 \mathrm{~m}$, and only 2 over greater distances (Table 4).

As also recorded in US, 2013 was characterized by a very late snowmelt, with snow cover in the upper part of the basin lasting until the end of May. On 21 May 2013 $\left(Q_{\max }=0.38 \mathrm{~m}^{3} \mathrm{~s}^{-1}\right)$ we recorded that 120 clast (out of 164 recovered) did not move, 42 moved over relatively short distances $(<10 \mathrm{~m})$, and only 2 moved further away $(<30 \mathrm{~m})$. By 2 July 2013, after the high snowmelt flows $\left(Q_{\max }=1.81 \mathrm{~m}^{3} \mathrm{~s}^{-1}\right)$ had ceased, we observed the displacement of 158 clasts (out of 164 recovered). In particular, 105 tracers travelled for more than $500 \mathrm{~m}, 11$ of which between 300 and $500 \mathrm{~m}$, with a peak displacement of $927 \mathrm{~m}$ (Table 4). Displacements associated with summer storms were assessed on 2 October $2013\left(Q_{\max }=1.01 \mathrm{~m}^{3} \mathrm{~s}^{-1}\right)$. By this date, 78 clasts (out of 130 recovered) had moved, mostly across relatively short distances $(60$ clasts $<10 \mathrm{~m} ; 11$ between 10 and $30 \mathrm{~m}$, and only $1>30 \mathrm{~m}$ ), but with some exceptionally high peaks ( 959 and $918 \mathrm{~m}$ for single clasts belonging respectively to W1 and W2). All weight classes moved, with the heaviest presenting peak displacements of $7.7 \mathrm{~m}$ (W7) and $10.0 \mathrm{~m}$ (W8). In the final post-snowmelt survey, conducted on 16 July $2014\left(Q_{\max }=1.51 \mathrm{~m}^{3} \mathrm{~s}^{-1}\right)$, we observed displacements in all weight classes, with a combined mobilization of 82 tracers (out of 127 recovered). In particular, we measured a peak travel distance of $958 \mathrm{~m}$ (W5); we recorded that 10 clasts had travelled between 300 and $500 \mathrm{~m}$ and 8 clasts further away (Table 4).

Summary information on clast movements for each weight class and stratified by travel distance (Fig. 6, right-hand pan- 

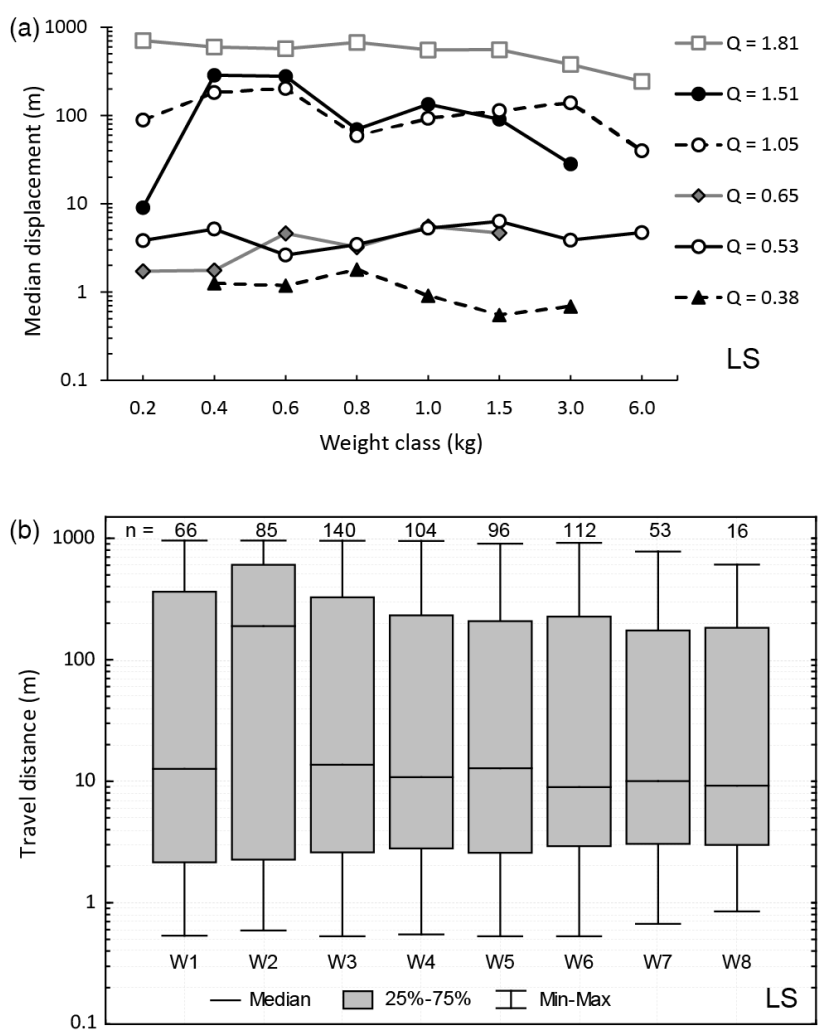

Weight class $(\mathrm{kg})$

Figure 8. (a) Tracer median travel distance as a function of weight and stratified by intra-survey peak discharge $\left(Q_{\max }\right)$ in Lower Strimm (LS). (b) Box plot showing the distribution of tracer travel distances across weight classes in Lower Strimm (LS). No motion counts are excluded.

els; Table S2 in the Supplement) also confirms for LS the seasonal character observed in US, with largest displacements associated with snowmelt hydrographs. In particular, in the three surveys conducted in June and July we recorded tracer displacement $>50 \mathrm{~m}$ in all weight categories (W1 to W8) (Fig. 6k, o and q), whereas similar-magnitude step lengths associated with rainfall-induced events were observed in some weight classes in 2013 only (Fig. 6p).

Median travel distances at LS are more sensitive to $Q_{\max }$ (Fig. 8a) compared to what was observed at US (Fig. 7a), as they range over 3 orders of magnitude. In contrast, the decrease in travel distance (in terms of maximum, median, and quartiles) with increasing particle weight is less pronounced in US (Fig. 7b) than at LS (Fig. 8b). Indeed, displacement data at LS indicate that all the clasts within the analysed size range (representing the "ordinary" bedload flux) move along similar distances for a given flow condition. Overall, within the explored range of sediment size, Fig. 8 (along with Fig. 6) clearly shows how the dependency of bedload travel distance on particle weight is rather low in both segments of Strimm Creek, corroborating the general tendency to near- equimobility conditions (see Lenzi, 2004) already observed analysing the critical discharges for tracers motion. Such a behaviour is more evident in LS than in US, as transport data for the latter display higher variability across tracer weight categories and a consistent decreasing pattern of the maximum travel distance (Fig. 7b).

\subsection{Particle virtual velocities and estimated bedload volumes}

The flow competence method (Eq. 1) allowed for entrainment thresholds to be identified for the two study sites. At US, we found that discharges $>0.32 \mathrm{~m}^{3} \mathrm{~s}^{-1}$ were able to mobilize clasts from any weight class (W1 to W6). This figure is slightly lower than what estimated at LS, where entrainment across all classes (W1 to W8) occurred for flows $>0.38 \mathrm{~m}^{3} \mathrm{~s}^{-1}$. Given the uncertainty associated with water discharge at LS, we consider the two values not significantly different.

Thresholds for sediment motion in US and LS were used to estimate the integral duration of transport for each tracer class. These values were then used to calculate tracer virtual velocity for each inter-survey period, defined as the ratio between the mean displacement length and the integral transport time. In US, box plots of virtual velocities as a function of inter-survey peak flow (Fig. 9a) identify a high-velocity envelope $\left(0.1<\bar{v}<10 \mathrm{~cm} \mathrm{~min}^{-1}\right)$ for low flows $\left(Q_{\max } \leq 0.36 \mathrm{~m}^{3} \mathrm{~s}^{-1}\right)$, and a low-velocity one $(0.001<\bar{v}$ $<0.1 \mathrm{~cm} \mathrm{~min}^{-1}$ ) for higher flows. At first sight, this behaviour appears counterintuitive. However, when stratifying peak flows in snowmelt, rainstorm-driven and mixed regimes (cf. Fig. 4), and recalling that clast virtual velocity may include both travelling and resting periods, it becomes apparent that the high-velocity envelope is associated with shortduration (i.e. hours) summer storms. In these periods, characterized by lower peak discharges, a greater precision on the identification of the threshold discharges is possible, so that the integral time calculated for virtual velocities tends to approach the real time of the particle movement, resulting in virtual velocities that are more representative of the tracer's actual velocity. Conversely, the low-velocity envelope is the expression of long-duration, sustained snowmelt flows (i.e. months) wherein potentially long resting periods are present as well. The fact that for purely snowmelt intersurvey periods median virtual velocity increases gradually with peak flow (i.e. $Q_{\max }=0.72 \mathrm{~m}^{3} \mathrm{~s}^{-1}$ is associated with a mixed hydrologic forcing including part of the exceptionally long 2013 snowmelt runoff and summer storms, cf. Fig. 4) seems to corroborate this interpretation.

In LS we observe a more complex pattern in that rainfalland snowmelt-dominated inter-survey periods cannot be discriminated in terms of virtual velocities (Fig. 9b), possibly as a consequence of integrating a larger drainage area (i.e. for convective summer storms) and lower elevations (i.e. for snowmelt events). Interestingly, mixed snowmelt-rainfall pe- 
Table 5. Median virtual velocities (Vv) and virtual transport duration at US.

\begin{tabular}{lrrrr}
\hline Type & $\begin{array}{r}Q_{\text {max }} \\
\left(\mathrm{m}^{3} \mathrm{~s}^{-1}\right)\end{array}$ & $\begin{array}{r}\text { Inter-survey } \\
\text { length } \\
\text { (days) }\end{array}$ & $\begin{array}{r}\text { Median Vv } \\
\left(\mathrm{cm} \mathrm{min}^{-1}\right)\end{array}$ & $\begin{array}{r}\text { Virtual transport } \\
\text { duration } \\
(\mathrm{min})\end{array}$ \\
\hline Rain & 0.36 & 28 & 0.6600 & 60 \\
Snowmelt & 0.66 & 260 & 0.0020 & 29570 \\
Snowmelt & 0.55 & 19 & 0.0018 & 27060 \\
Rain & 0.33 & 70 & 0.3461 & 130 \\
Rain & 0.32 & 23 & 4.4000 & 10 \\
Snowmelt & 1.13 & 266 & 0.0074 & 20890 \\
Mixed & 0.72 & 96 & 0.0011 & 52370 \\
Snowmelt & 0.95 & 255 & 0.0045 & 22220 \\
\hline
\end{tabular}

Table 6. Median virtual velocities (Vv) and virtual transport duration at LS.

\begin{tabular}{lrrrr}
\hline Type & $\begin{array}{r}Q_{\text {max }} \\
\left(\mathrm{m}^{3} \mathrm{~s}^{-1}\right)\end{array}$ & $\begin{array}{r}\text { Inter-survey } \\
\text { length } \\
\text { (days) }\end{array}$ & $\begin{array}{r}\text { Median Vv } \\
\left(\mathrm{cm} \mathrm{min}^{-1}\right)\end{array}$ & $\begin{array}{r}\text { Virtual transport } \\
\text { duration } \\
(\mathrm{min})\end{array}$ \\
\hline Rain & 0.58 & 32 & 0.0768 & 6575 \\
Mixed & 0.53 & 234 & 0.0092 & 41670 \\
Snowmelt & 1.05 & 41 & 0.1938 & 58870 \\
Mixed & 0.65 & 54 & 0.0168 & 22590 \\
Rain & 0.51 & 65 & 0.3991 & 470 \\
Snowmelt & 0.38 & 208 & 1.8432 & 60 \\
Snowmelt & 1.81 & 42 & 1.7501 & 33330 \\
Mixed & 1.01 & 92 & 0.0029 & 108970 \\
Snowmelt & 1.51 & 287 & 0.1654 & 103080 \\
\hline
\end{tabular}

riods $\left(Q_{\max }=0.53,0.65\right.$ and $\left.1.01 \mathrm{~m}^{3} \mathrm{~s}^{-1}\right)$ cluster consistently lower than snowmelt- and rainfall-dominated ones. Inspection of the hydrograph shape (Fig. 4) and the virtual transport duration values (Tables 5 and 6) (i.e. time for which $Q>$ threshold $Q_{\max }$ for bedload entrainment) is instructive. From the premise that "mixed" and purely snowmelt periods display comparable virtual transport durations (Tables 5 and 6), we argue that mixed periods are characterized by low virtual velocities because they integrate the second half of the snowmelt season (i.e. past the main snowmelt peak). Accordingly, at this time of the year, even though water discharge is well above the threshold $Q_{\max }$ associated with flashy summer storms (i.e. 0.32 and $0.38 \mathrm{~m}^{3} \mathrm{~s}^{-1}$ ), the nearly flat hydrograph shape of the snowmelt falling limb promotes channel bed stabilization (e.g. Hassan et al., 2006), with reduced bedload transport (e.g. Green et al., 2013) and lowest virtual velocities.

In order to gain further insights into the effects that hydrometeorological forcing can exert on bedload sediment transport, virtual velocities of single tracers were plotted - for selected inter-survey periods - as a function of their weight (Fig. 10). In particular, we compare the effects of the same snowmelt (i.e. spring-summer 2013) and rainfall season (i.e. summer-fall 2012) on tracer virtual velocity in US and LS. Results show that rainfall-induced peak flows have almost identical effects in the two study sites by imparting virtual velocities clustered between 0.1 and $3 \mathrm{~cm} \mathrm{~min}^{-1}$. Results show
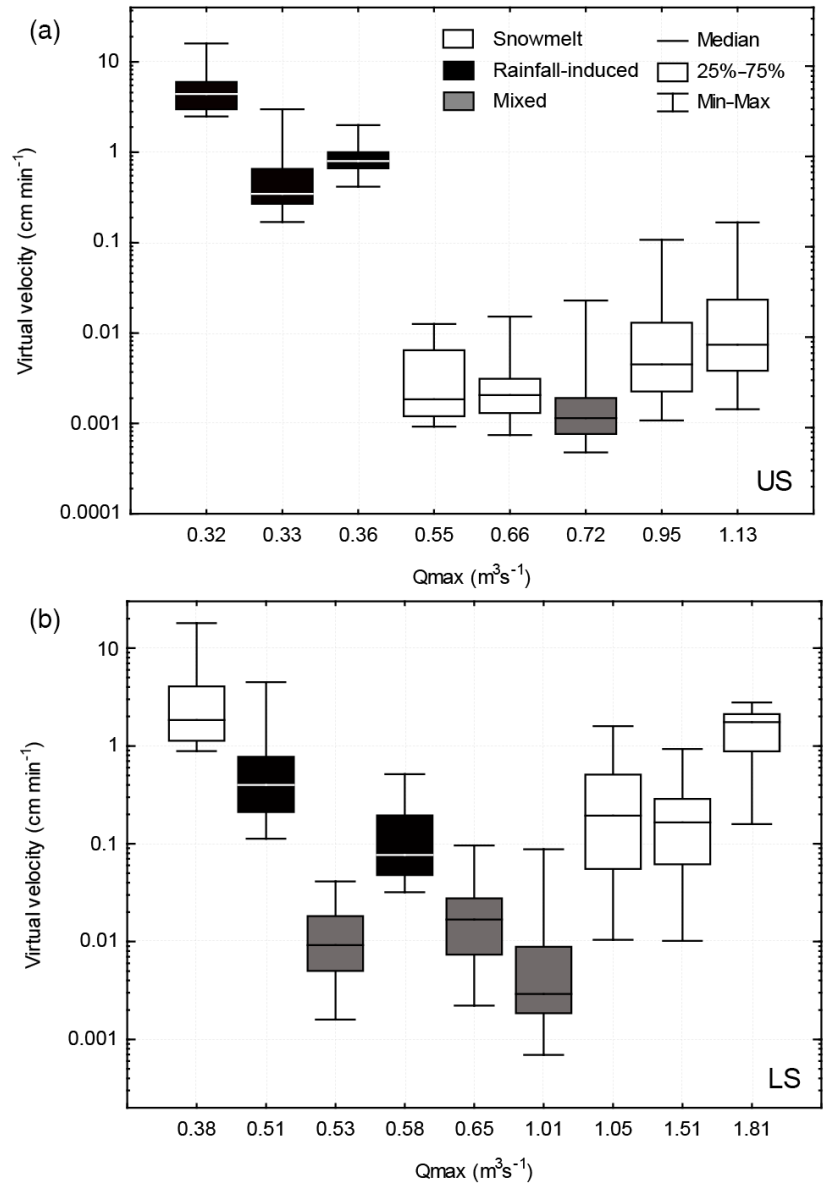

Figure 9. Box plots of the tracers' virtual velocities in relation to the corresponding inter-survey peak discharge $\left(Q_{\max }\right)$ in (a) Upper Strimm (US) and (b) Lower Strimm (LS). The flow regime of inter-survey periods is classified into snowmelt, rainfall-induced, and mixed. Mixed periods represent a combination of the first two and typically correspond to the snowmelt falling limb.

that rainfall-induced peak flows have almost identical effects in the two study sites by imparting virtual velocities clustered between 0.1 and $3 \mathrm{~cm} \mathrm{~min}^{-1}$. In these two instances, we observe a direct weak correlation between tracer weight and virtual velocity (red triangles in Fig. 10). In these instances, we reckon that heavier clasts move faster than the others because once they are in motion, they are subjected to higher water velocities (due to their higher protrusion into the flow) and are more capable than finer particles of passing over locally slow, rough bed patches, thanks to their higher momentum. In this way, they find fewer opportunities to stop once they are entrained.

Following the approach based on tracer virtual velocities and the field-based evaluation of the active layer width and depth (see Sect. 3), we estimated the total bedload transport volumes in US (Table 7) and LS (Table 8) across the 3-year study period (Fig. 11). Cumulatively, in the monitored portions of US and LS, total bedload volumes amount to respec- 
Table 7. Estimates of sediment volumes $\left(\mathrm{m}^{3}\right)$ transported at Upper Strimm.

\begin{tabular}{lcccccccc}
\hline Survey & 28 Sep 2011 & 14 Jun 2012 & 3 Jul 2012 & 11 Sep 2012 & 4 Oct 2012 & 27 Jun 2013 & 1 Oct 2013 & 13 Jun 2014 \\
\hline$Q_{\max }\left(\mathrm{m}^{3} \mathrm{~s}^{-1}\right)$ & 0.36 & 0.66 & 0.55 & 0.33 & 0.32 & 1.13 & 0.72 & 0.95 \\
\hline $\mathrm{V}\left(\mathrm{m}^{3}\right)$ & 0.206 & 0.256 & 0.224 & 0.362 & 0.111 & 1.096 & 0.488 & 1.060 \\
\hline
\end{tabular}

Table 8. Estimates of sediment volumes $\left(\mathrm{m}^{3}\right)$ transported at Lower Strimm.

\begin{tabular}{lccccccccc}
\hline Survey & 27 Sep 2011 & 18 May 2012 & 28 Jun 2012 & 21 Aug 2012 & 25 Oct 2012 & 21 May 2013 & 2 Jul 2013 & 2 Oct 2013 & 16 Jul 2014 \\
\hline$Q_{\max }\left(\mathrm{m}^{3} \mathrm{~s}^{-1}\right)$ & 0.58 & 0.53 & 1.05 & 0.65 & 0.51 & 0.38 & 1.81 & 1.01 & 1.51 \\
\hline $\mathrm{V}\left(\mathrm{m}^{3}\right)$ & 3.533 & 3.104 & 121.965 & 2.396 & 8.742 & 0.996 & 334.614 & 24.828 & 89.520 \\
\hline
\end{tabular}
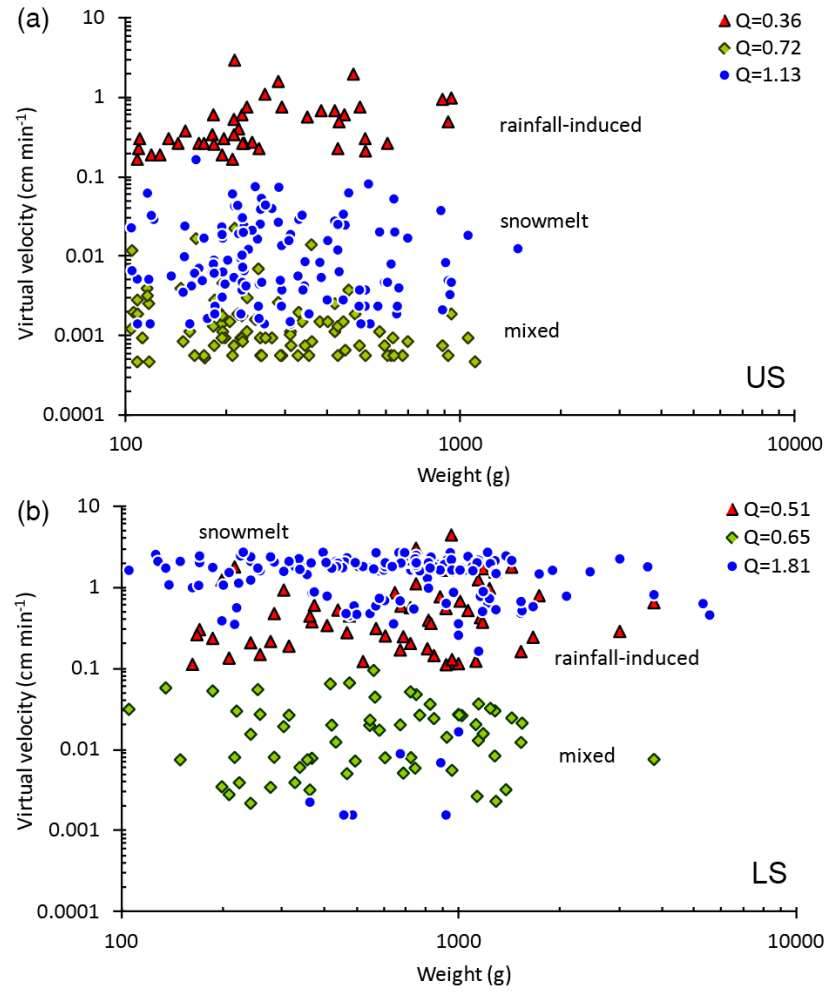

Figure 10. Tracers' virtual velocities as a function of weight for three selected peak discharges in Upper Strimm (a) and in Lower Strimm (b). The selected peak discharges for US and LS correspond to the same inter-survey periods and therefore are directly comparable. Red triangles refer to rainfall-induced velocities (i.e. summerfall 2012), blue circles to snowmelt-related velocities (i.e. springsummer 2013), and green diamonds to mixed snowmelt-rainfall periods. Note that, in both study areas, tracer virtual velocities are independent of weight.

tively 3.3 and $590 \mathrm{~m}^{3}$ (Fig. 11b), which correspond to a transport rate of approximately 2.9 and 511 tonnes per year. In agreement with what noted above in terms of virtual velocity clustering for different hydro-meteorological forcing (cf. box plots in Fig. 9a and b), this 2 orders of magnitude difference
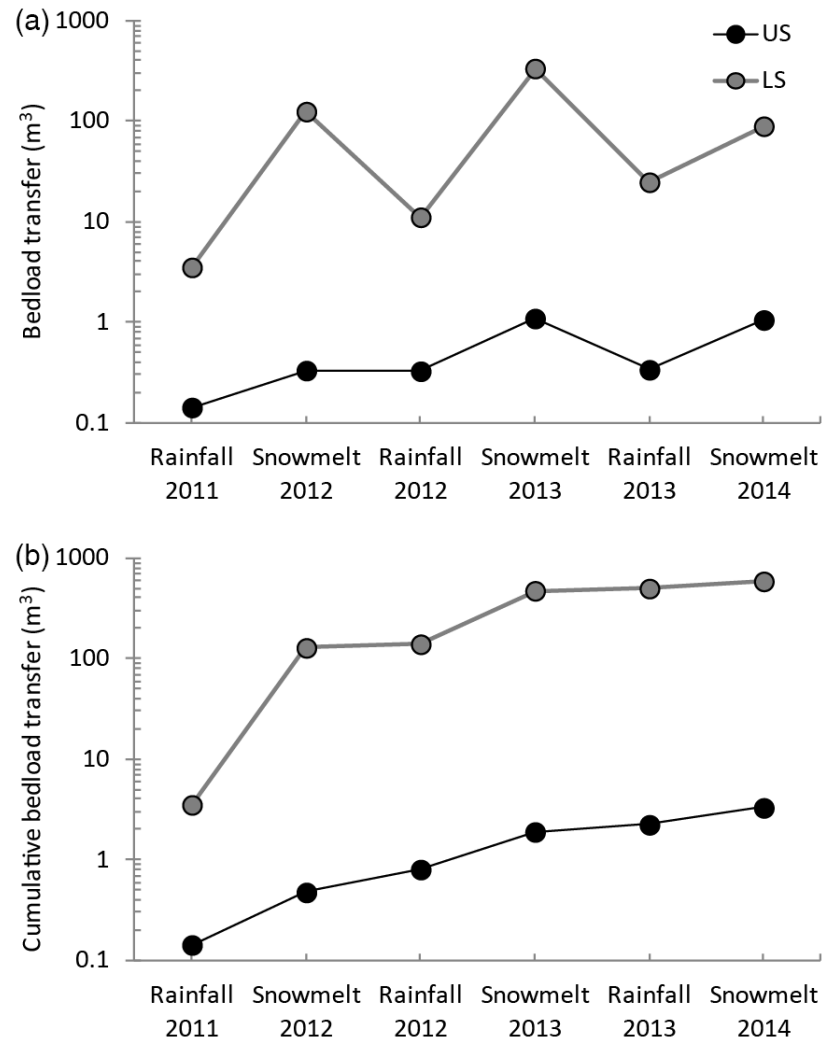

Figure 11. Non-cumulative (a) and cumulative (b) seasonal representation of estimated bedload volumes transported in Upper Strimm (US) and Lower Strimm (LS). Note the efficiency of snowmelt transport periods and the difference of nearly 2 orders of magnitude between US and LS.

is mainly controlled by the dominance of snowmelt-driven bedload transport in LS (Fig. 11a), and to a lesser extent by rainfall and mixed events. Specifically, snowmelt-related transport accounted for $75 \%$ in US and $93 \%$ in LS of the total bedload flux. 


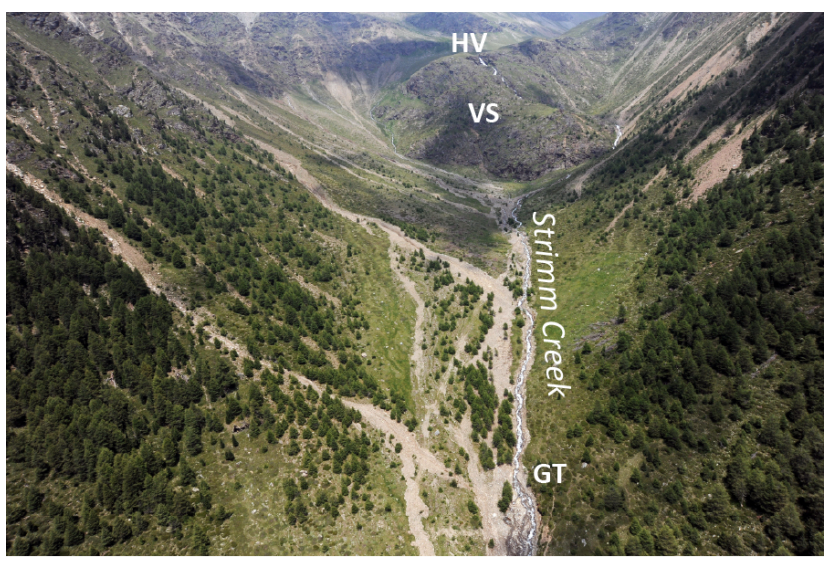

Figure 12. Oblique aerial view of the mid-Strimm Creek basin taken after the storm event of 12 July 2010. Note the lateral colluvial channels activated during the event that have delivered material directly to Strimm Creek, activating a debris flow, which transformed downstream into a debris flood, depositing about $15000 \mathrm{~m}^{3}$ of debris in the retention basin located at the basin outlet. Visible in the background are the hanging valley (HV) and the rocky valley step (VS) that joins abruptly with the U-shaped relict glacial trough (GT). Photo courtesy of the province of Bolzano.

\section{Discussion}

The structure of the Strimm Basin is the result of Pleistocene glacial activity that reshaped the complex, tectonically controlled landscape structures typical of the Austroalpine metamorphic domain. As a result, the spatial organization of relict glacial macro-forms bears some structurally controlled inheritance. In the case of Strimm Creek, the main valley step is of glacial origin, as it is not associated with any fault line or lithological contact/discontinuity (Corrado Morelli, Geological Survey of Bolzano, personal communication, 2015). Specifically, it is the result of differential glacial erosion associated with the main relict ice flow of the Adige Valley and the tributary cirque glacier located at the headwaters of Strimm Creek (i.e. the hanging valley in US). This landscape structure, by imposing local channel slope and the degree of hillslope-channel connectivity, has affected, and still controls, the pace of postglacial landscape evolution in different portions of Strimm Creek. In particular, Upper Strimm Creek flows through a relatively gentle channel bed in decoupled conditions, i.e. buffered from lateral hillslope sediment inputs (Brunsden and Thornes, 1979; Fryirs et al., 2007), characterized by indices of stream power that are about 1 order of magnitude smaller than in the steeper and strongly coupled Lower Strimm Creek (Cavalli et al., 2013). Contrasting hillslope-channel coupling conditions in the two study sites have generated strikingly different channel types on the opposite sides of the rocky valley step, including purely alluvial channel reaches in US $\left(D_{84}=119 \mathrm{~mm} ; D_{90}=148 \mathrm{~mm}\right)$ and much rougher, semi-alluvial ones (e.g. Halwas and Church, $2002)$ in LS ( $\left.D_{84}=281 \mathrm{~mm} ; D_{90}=368 \mathrm{~mm}\right)$.

By means of a 3-year bedload tracing effort, we show that the contrasting channel boundary conditions at US and LS respond in markedly different ways to the snowmelt-dominated hydrologic regime of the study basin, which is characterized by low annual and summer precipitation. Here, sediment transporting flows occur during snowmelt (generally between mid-May and late June), and to a lesser extent during summer convective storms. Cyclonic fronts from late October through to November typically bring snow to the upper basin; thus autumn floods do not occur. In both study sites, we observe that most of the bedload material is mobilized during the snowmelt period, but with tracer maximum travel distances in LS that are 1 to 2 orders of magnitude larger than in US. In particular, while rainfall-dominated periods impart similar virtual velocities to the study tracers in US and LS (Fig. 9), snowmelt and mixed periods in LS are associated with virtual velocities that are nearly an order of magnitude higher than in US. Regardless of the hydro-meteorological regime, at both sites tracer virtual velocities appear to be nearly independent of tracer weight (Fig. 10).

In US, bedload transport appears to function in a weakly weight-selective fashion, with tracers heavier than $1 \mathrm{~kg}$ being mobilized sporadically and for distances $<10 \mathrm{~m}$. By contrast, in LS, characterized by roughly $60 \%$ higher peak discharges, all the monitored clast categories tend to move across comparable orders of distances, with snowmelt events able to transport heavier particles $(>5 \mathrm{~kg}$ ) for distances $>50 \mathrm{~m}$. These quantitative observations translate, for a given snowmelt event, into virtual velocities that in LS are about 2 orders of magnitude higher than in US, whereas rainfall-driven transport events are associated with more comparable figures in the two study sites. In turn, such a disparity in tracer virtual velocities results in amplified differences in terms of estimated bedload transport volumes, so that, in the entire study period, about $200 \mathrm{~m}^{3} \mathrm{yr}^{-1}$ was transported in LS, as opposed to only a little more than $1 \mathrm{~m}^{3} \mathrm{yr}^{-1}$ in US. Of these volumes, snowmelt flows are responsible for respectively 93 and $75 \%$ of the total in LS and US.

In order to fully estimate contemporary rates of sediment transfer in the Strimm Creek basin, it is important to consider the "ordinary" bedload transport volumes estimated during the study period in conjunction with high-magnitude events able to reorganize the streambed, in particular with the sediment volume transported during the large complex event occurred on 12 July 2010 (Fig. 12). On that occasion, about $22 \mathrm{~mm}$ of rain (measured approximately within $20 \mathrm{~min}$ at gauge R1) triggered a debris-flow event that reached the retention dam at the basin outlet (Fig. 1). The post-event survey, conducted by some of the authors together with technicians of the local river basin agency, identified complex spatial dynamics. While the main channel up in the US site showed no evidence of significant bedload transport or bed changes, most of the western colluvial tributaries located 
just downstream of the valley step were affected by debris flows, which fed the main channel with large sediment supply (Fig. 12). Peak discharges of up to $40-50 \mathrm{~m}^{3} \mathrm{~s}^{-1}$ were estimated at the LS site, where the flow was probably a debris flood (Hungr, 2005), based on direct morphological and sedimentological field evidence. However, only moderate incision was apparent at the LS site after the event. More severe incision occurred in the steep, lowermost reach of Strimm Creek, where several landslides were triggered by slope undercutting and increase the sediment concentration of the flow, probably up to debris-flow levels.

The topographic survey conducted at the retention basin (Fig. 1) determined that the 2010 event transported about $15000 \mathrm{~m}^{3}$ of debris. This event represents the largest recorded in the provincial geo-hazard database for the study basin, and locals claim that an event of similar magnitude occurred only back in the 1930s. Remarkably, this volume of material, which was all recruited downstream of the rocky valley step, corresponds to an equivalent of about 2025 years of "ordinary" bedload transport, making Strimm Creek, under the present climatic conditions, a bedloaddominated system.

The implications for long-term landscape evolution in Strimm Creek are intriguing as we are looking at two portions of the same basin that are functioning at markedly different speeds, and therefore characterized by a different geomorphic sensitivity to change (Brunsden and Thornes, 1979). Upper Strimm Creek is a typical "slow-response" subsystem, in which, due to generalized hillslope-channel disconnection and to inefficient bedload transport, any perturbation through the hillslopes and the drainage network is either blocked or damped. By contrast, Lower Strimm Creek represents a highly sensitive, fast-responding system thanks to the high degree of hillslope-to-channel sediment delivery, together with much higher bedload transport. In consideration of the limited bedload transport recorded at US, which implies a limited supply of clasts to the rocky valley step separating US from LS, we postulate that the valley step will undergo extremely slow bedrock incision, due to the limited tool effect acting on the sub-vertical rocky channel (e.g. Finnegan et al., 2007; Turowski et al, 2007). This hypothesis is supported by the only limited bedrock incision achieved by Strimm Creek in the last 12000 years since deglaciation.

\section{Conclusions}

By tracking bedload particle movement simultaneously at two sites, we quantify an increase in bedload transport greater than 2 orders of magnitude moving from the hanging valley in Upper Strimm Creek, through the disconnecting rocky valley step, and down to the reaches within the glacial trough in Lower Strimm Creek. We show that geomorphic conditions of hillslope-channel decoupling correspond to comparatively lower rates of downstream sediment fining (i.e. $28.4 \mathrm{~mm} \mathrm{~km}^{-1}$ ) and to low, within-channel sedi- ment connectivity (i.e. low bedload transport) along the monitored reaches in US. Conversely, strongly coupled conditions ensure strikingly increased efficiency in sediment evacuation, as confirmed by the 10-fold increase in snowmeltrelated virtual velocities, and stronger downstream sediment fining (i.e. $40.5 \mathrm{~mm} \mathrm{~km}^{-1}$ ) in LS reaches.

Despite the limited length of record and the uncertainty associated with the calculation of bedload transport volumes, the combination of debris-flow/flood activity, together with estimates of 15 bedload transport events, document contrasting rates of landscape down-wasting in the upper and lower portions of the investigated basin. These findings point to a postglacial evolution in which glacial topographic signatures (e.g. Brardinoni and Hassan, 2006) will likely amplify rather than reduce. In particular, the low rate of bedload material supplied to the bedrock channel cutting through the valley step will keep the "tool effect" to low levels of efficiency, whereas the degree of channelized landscape dissection in LS will continue to grow comparatively faster thanks to the combined work of bedload and mass-wasting processes. Low sediment supply to glacially carved bedrock gorges may represent a key mechanism for the virtually intact preservation of valley steps across interglacial periods.

\section{The Supplement related to this article is available online at doi:10.5194/esurf-3-527-2015-supplement.}

Acknowledgements. This project was funded through "Monitor II" (EU Interreg South-East Europe), "GESTO" (granted by the Autonomous Province of Bolzano) and "SEDALP" (EU Alpine Space programme). Gianluca Abram, Giulia Bonfanti, Alex Boninsegna, Enrico Buzzi, Marco Chiolo, Giacomo Falsitta, Raffaele Foffa, Ana Lucìa, Alberto Maggioni, Enrico Marchese, and Emilio Perina are acknowledged for their precious field assistance. Constructive and thoughtful reviews of two anonymous referees helped improving the manuscript and are greatly acknowledged.

Edited by: E. Lajeunesse

\section{References}

Andrews, E. D.: Entrainment of gravel from naturally sorted riverbed material, Geol. Soc. Am. Bull., 94, 1225-1231, 1983.

Armstrong, J. D., Braithwaite, V. A., and Rycroft, P.: A flat-bed passive integrated transponder antenna array for monitoring behaviour of Atlantic salmon parr and other fish, J. Fish Biol., 48 , 539-541, 1996.

Bathurst, J. C.: Measuring and modelling bedload transport in channels with coarse bed materials, in: River Channels - Environment and Process, edited by: Richards, K., Blackwell, Oxford, UK, 272-294, 1987.

Bracken, L. J., Turnbull, L., Wainwright, J., and Bogaart, P.: Sediment connectivity: a framework for understanding sediment 
transfer at multiple scales, Earth Surf. Proc. Land., 40, 177-188, doi:10.1002/esp.3635, 2015.

Bradley, D. N. and Tucker, G. E.: Measuring gravel transport and dispersion in a mountain river using passive radio tracers, Earth Surf. Proc. Land., 37, 1034-1045, 2012.

Brardinoni, F. and Hassan, M. A.: Glacial erosion, evolution of river long-profiles, and the organization of process domains in mountain drainage basins of coastal British Columbia, J. Geophys. Res., 111, F01013, doi:10.1029/2005JF000358, 2006.

Brardinoni, F. and Hassan, M. A.: Glacially-induced organisation of channel-reach morphology in mountain streams, J. Geophys. Res., 112, F03013, doi:10.1029/2006JF000741, 2007.

Brardinoni, F., Hassan, M. A., Rollerson, T., and Maynard, D.: Colluvial sediment dynamics in mountain drainage basins, Earth Planet. Sc. Lett., 284, 310-319, 2009.

Brardinoni, F., Church, M., Simoni, A., and Macconi, P.: Lithologic and glacially-conditioned controls on debris-flow sediment dynamics, Geology, 40, 455-458, 2012.

Brummer, C. J. and Montgomery, D. R.: Downstream coarsening in headwater channels, Water Resour. Res., 39, 1294, doi:10.1029/2003WR001981, 2003.

Brunsden, D. and Thornes, J. B.: Landscape sensitivity and change, T. I. Brit. Geogr., 4, 463-484, 1979.

Bunte, K. and Abt, S. R.: Sampling surface and subsurface particlesize distributions in wadable gravel-and cobble-bed streams for analyses in sediment transport, hydraulics, and streambed monitoring, Gen. Tech. Rep. RMRS-GTR-74, U. S. Department of Agriculture, Forest Service, Rocky Mountain Research Station, Fort Collins, CO, USA, 428 pp., 2001.

Camenen, B., Le Coz, J., Paquier, A., and Lagouy, M.: An estimation of gravel mobility over an alpine river gravel bar (Arc en Maurienne, France) using PIT-tag tracers, in: 5th International Conference on Fluvial Hydraulics (River Flow 2010), 8-10 September 2010, Braunschweig, Germany, 953-960, 2010.

Cavalli, M., Trevisani, S., Comiti, F., and Marchi, L.: Geomorphometric assessment of spatial sediment connectivity in small Alpine catchments, Geomorphology, 188, 31-41, 2013.

Chapuis, M., Bright, C. J., Hufnagel, J., and MacVicar, B. Detection ranges and uncertainty of passive Radio Frequency Identification (RFID) transponders for sediment tracking in gravel rivers and coastal environments, Earth Surf. Proc. Land., 39, 2109-2120, 2014.

Church, M. and Hassan, M. A.: Size and distance of travel of unconstrained clasts on a streambed, Water Resour. Res., 28, 299-303, 1992.

Comiti, F. and Mao, L.: Recent advances in the dynamics of steep channels, in: Gravel-Bed Rivers: Processes, Tools, Environments, John Wiley \& Sons, Chichester, UK, 351-377, 2012.

Comiti, F., Marchi, L., Macconi, P., Arattano, M., Bertoldi, G., Borga, M., Brardinoni, F., Cavalli, M., D’Agostino, V., Penna, D., and Theule, J.: A new monitoring station for debris flows in the European Alps: first observations in the Gadria basin, Nat. Hazards, 73, 1175-1198, 2014.

D'Agostino, V. and Lenzi, M. A.: Bedload transport in the instrumented catchment of the Rio Cordon: Part II: Analysis of the bedload rate, Catena, 36, 191-204, 1999.

Ergenzinger, P. J. and Custer, S. G.: Determination of bedload transport using naturally magnetic tracers: first experiences at Squaw
Creek, Gallatin County, Montana, Water Resour. Res., 19, 187193, 1983.

Finnegan, N. J., Sklar, L. S., and Fuller, T. K.: Interplay of sediment supply, river incision, and channel morphology revealed by the transient evolution of an experimental bedrock channel, J. Geophys. Res.-Earth. (2003-2012), 112, F03S11, doi:10.1029/2006JF000569, 2007.

Fryirs, K. A., Brierley, G. J., Preston, N. J., and Kasai, M.: Buffers, barriers and blankets: the (dis) connectivity of catchment-scale sediment cascades, Catena, 70, 49-67, 2007.

Gilbert, G. K. and Murphy, E. C.: The transportation of debris by running water, Vol. 86, US Government Printing Office, Washington, USA, 1914

Gomez, B. and Church, M.: An assessment of bed load sediment transport formulae for gravel bed rivers, Water Resour. Res., 25, 1161-1186, 1989.

Green, K. C., Brardinoni, F., and Alila, Y. Channel morphology and bed-load yield in fluvial, formerly-glaciated headwater streams of the Columbia Mountains, Canada, Geomorphology, 188, 96109, 2013

Green, K. G, Alila, Y., and Brardinoni, F.: Patterns of bedload entrainment and transport in forested headwater streams of the Columbia Mountains, Canada, Earth Surf. Proc. Land., 40, $427-$ 446, doi:10.1002/esp.3642, 2015.

Habersack, H. M. and Laronne, J. B.: Evaluation and improvement of bed load discharge formulas based on Helley-Smith sampling in an alpine gravel bed river, J. Hydraul. Eng., 128, 484-499, 2002.

Habler, G., Thöni, M., and Grasemann, B.: Cretaceous metamorphism in the Austroalpine Matsch Unit (Eastern Alps): the interrelation between deformation and chemical equilibration processes, Miner. Petrol., 97, 149-171, 2009.

Halwas, K. L. and Church, M.: Channel units in small, high gradient streams on Vancouver Island, British Columbia, Geomorphology, 43, 243-256, 2002

Haschenburger, J. K. and Church, M.: Bed material transport estimated from the virtual velocity of sediment, Earth Surf. Proc. Land., 23, 791-808, 1998.

Hassan, M. A. and Ergenzinger, P.: Use of tracers in fluvial geomorphology, in: Tools in Fluvial Geomorphology, John Wiley \& Sons, Chichester, UK, 397-423, 2003.

Hassan, M. A., Church, M., and Schick, A. P.: Distance of movement of coarse particles in gravel bed streams, Water Resour. Res., 27, 503-511, 1991.

Hassan, M. A., Church, M., and Ashworth, P. J.: Virtual rate and mean distance of travel of individual clasts in gravel-bed channels, Earth Surf. Proc. Land., 17, 617-627, 1992.

Hassan, M. A., Egozi, R., and Parker, G.: Experiments on the effect of hydrograph characteristics on vertical grain sorting in gravel bed rivers, Water Resour. Res., 42, W09408, doi:10.1029/2005WR004707, 2006.

Hassan, M. A., Voepel, H., Schumer, R., Parker, G., and Fraccarollo, L.: Displacement characteristics of coarse fluvial bed sediment, J. Geophys. Res.-Earth, 118, 155-165, 2013.

Hoffmann, T., Muller, T., Johnson, E. A., and Martin, Y. E.: Postglacial adjustment of steep, low-order drainage basins, Canadian Rocky Mountains, J. Geophys. Res.-Earth, 118, 2568-2584, 2013. 
Houbrechts, G., Van Campenhout, J., Levecq, Y., Hallot, E., Peeters, A., and Petit, F.: Comparison of methods for quantifying active layer dynamics and bedload discharge in armoured gravel-bed rivers, Earth Surf. Proc. Land., 37, 15011517, doi:10.1002/esp.3258, 2012.

Hungr, O.: Classification and terminology, in: Debris-Flow Hazards and Related Phenomena, edited by: Jakob, M. and Hungr, O., Springer, Berlin, Germany, 9-23, 2005.

Johnston, P., Bérubé, F., and Bergeron, N. E.: Development of a flatbed passive integrated transponder antenna grid for continuous monitoring of fishes in natural streams, J. Fish Biol., 74, 1651-1661, 2009.

Lamarre, H. and Roy, A. G.: A field experiment on the development of sedimentary structures in a gravel-bed river, Earth Surf. Proc. Land., 33, 1064-1081, 2008.

Lamarre, H., MacVicar, B., and Roy, A. G.: Using passive integrated transponder (PIT) tags to investigate sediment transport in gravel-bed rivers, J. Sediment. Res., 75, 736-741, 2005.

Laronne, J. B. and Carson, M. A.: Interrelationships between bed morphology and bed-material transport for a small, gravel-bed channel, Sedimentology, 23, 67-85, 1976.

Lenzi, M. A.: Displacement and transport of marked pebbles, cobbles and boulders during floods in a steep mountain stream, Hydrol. Process., 18, 1899-1914, 2004.

Leopold, L. B., Emmett, W. W., and Myrick, R. M.: Channel and Hillslope Processes in a Semiarid Area, New Mexico, US Government Printing Office, Washington, USA, 193-253, 1966.

Liébault, F. and Laronne, J. B.: Evaluation of bedload yield in gravel-bed rivers using scour chains and painted tracers: the case of the Esconavette Torrent (southern French Prealps), Geodin. Acta, 21, 23-34, 2008.

Liébault, F., Bellot, H., Chapuis, M., Klotz, S., and Deschâtres, M.: Bedload tracing in a high-sediment-load mountain stream, Earth Surf. Proc. Land., 37, 385-399, 2012.

Mao, L. and Lenzi, M. A.: Sediment mobility and bedload transport conditions in an alpine stream, Hydrol. Process., 21, 1882-1891, 2007.

Martin, Y.: Evaluation of bed load transport formulae using field evidence from the Vedder River, British Columbia, Geomorphology, 53, 75-95, 2003.

Montgomery, D. R. and Buffington, J. M.: Channel reach morphology in mountain drainage basins, Geol. Soc. Am. Bull., 109, 596-611, 1997.
Nakato, T.: Tests of selected sediment-transport formulas, J. Hydraul. Eng., 116, 362-379, 1990.

Nichols, M. H.: A radio frequency identification system for monitoring coarse sediment particle displacement, Appl. Eng. Agric., 20, 783-787, 2004.

Nitsche, M., Rickenmann, D., Turowski, J. M., Badoux, A., and Kirchner, J. W.: Evaluation of bedload transport predictions using flow resistance equations to account for macro-roughness in steep mountain streams, Water Resour. Res., 47, W08513, doi:10.1029/2011WR010645, 2011.

Rickenmann, D.: Comparison of bed load transport in torrents and gravel bed streams, Water Resour. Res., 37, 3295-3305, 2001.

Schmidt, K. H. and Ergenzinger, P.: Bedload entrainment, travel lengths, step lengths, rest periods - studied with passive (iron, magnetic) and active (radio) tracer techniques, Earth Surf. Proc. Land., 17, 147-165, 1992.

Schneider, J., Hegglin, R., Meier, S., Turowski, J. M., Nitsche, M., and Rickenmann, D.: Studying sediment transport in mountain rivers by mobile and stationary RFID antennas, in: River Flow, Braunschweig, Germany, Bundesanstalt für Wasserbau (BAW), Vol. 2010, 1723-1730, 2010.

Schneider, J. M., Turowski, J. M., Rickenmann, D., Hegglin, R., Arrigo, S., Mao, L., and Kirchner, J. M.: Scaling relationships between bed load volumes, transport distances, and stream power in steep mountain channels, J. Geophys. Res.-Earth, 119, 533 549, 2014.

Sear, D. A., Damon, W., Booker, D. J., and Anderson, D. G.: A load cell based continuous recording bedload trap, Earth Surf. Proc. Land., 25, 659-672, 2000.

Takayama, S.: Bedload movement in torrential mountain streams, Tokyo Geography Papers, 9, 169-188, 1965.

Turowski, J. M., Lague, D., and Hovius, N.: Cover effect in bedrock abrasion: A new derivation and its implications for the modeling of bedrock channel morphology. J. Geophys. Res.-Earth (20032012), 112, F04006, doi:10.1029/2006JF000697, 2007.

Weekes, A. A., Torgersen, C. E., Montgomery, D. R., Woodward, A., and Bolton, S. M.: A process-based hierarchical framework for monitoring glaciated alpine headwaters, Environ. Manage., 50, 982-997, 2012.

Wohl, E.: Mountain Rivers Revisited, American Geophysical Union Monograph, Washington DC, USA, Vol. 19, 573 pp., 2010. 